\title{
El converso sevillano Nicolás Martínez de Medina (o de Sevilla), contador mayor de Castilla. Apuntes para una biografía*
}

\author{
Nicolás Martínez Medina (or de Sevilla), Sevilian Converso \\ and Chief Accountant of Castile. Notes for a Biography
}

\author{
ISABel Montes Romero-CAMACHO**
}

\begin{abstract}
RESUMEN
A partir de la conquista de Sevilla, en 1248, fueron muchos los judíos, primero, $y$ los conversos, después, que llegaron a ocupar una posición preeminente, tanto en la ciudad, como en la corte, desempeñando, casi siempre, importantes oficios, al servicio de la hacienda real castellana, en una secuencia prácticamente ininterrumpida que va desde Alfonso X (1252-1284) hasta la nueva dinastía Trastámara.

Uno de estos importantes conversos fue Nicolás Martínez de Medina (o de Sevilla), cuya actuación pública se desarrolló durante los reinados y a la sombra de los primeros Trastámara, desde Enrique II (1369-1379) hasta Juan II (1406-1454) y que, tras una brillante carrera en Sevilla y en la corte, llegaría a ser contador mayor de Castilla y, por tanto, uno de los personajes más influyentes de su época.
\end{abstract}

\author{
PALABRAS CLAVE \\ Conversos, Sevilla, Hacienda Real, \\ Castilla, Trastámara.
}

\section{ABSTRACT}

After the conquest of Seville in 1248, many Jews and later "Conversos» played a prominent role both in the city and in the Court. They occupied significant positions at the service of the Spanish royal treasury almost uninterruptedly from the reign of Alfonso X (1252-1284) to that of the new Trastámara dynasty.

One of these important «Conversos» was Nicolás Martínez de Medina (or de Sevilla), who held public positions under the reigns of the first Trastámara kings, from Enrique II (1369-1379) to Juan II (1406-1454). After a brilliant career in Seville and in the Court, he would become chief accountant of Castile and, consequently, one of the most influential individuals of his time.

\section{KEY WORDS}

«Conversos», Seville, Royal Treasury, Castile, Trastámara.

\footnotetext{
* Fecha de recepción del artículo: 2014-01-20. Fecha de admisión del artículo: 2014-02-13.

** Universidad de Sevilla. C.e.: imontes@us.es
} 


\section{INTRODUCCIÓN}

Como tantas veces se ha repetido, los judíos fueron la minoría étnico-religiosa más numerosa e importante de la Sevilla bajomedieval y su aljama era la segunda más importante de Castilla, a continuación de Toledo, la mayor del reino.

Es por ello que, a raíz mismo de la conquista cristiana, la comunidad hebrea sevillana se distinguió por contar entre sus miembros con unos pocos judíos principales que, además de ser muy ricos, representaron un importante papel en la vida pública, tanto sevillana, como castellana, por lo sus actuaciones iban más allá del reino de Sevilla, para extenderse por toda Castilla.

Entre las actividades más notables de estos hebreos sobresalían, especialmente, las que se relacionaban con la hacienda real, concejil o eclesiástica y también las que concernían al comercio del dinero o a las operaciones mercantiles de amplio radio. Normalmente, estaban organizados en fuertes clanes familiares, cuyos componentes, muchas veces expandidos por toda la corona de Castilla, actuaban de manera conjunta, lo que los hacía todavía más fuertes.

El devenir histórico de estos brillantes judíos sevillanos está marcado por dos fechas trascendentales: 1248, año de la conquista cristiana de Sevilla, y 1391, en el que se produjo el trágico asalto a la judería sevillana y que marcó el fin de su judería. A partir de la persecución de 1391, ciertamente, hubo judíos que siguieron viviendo en la ciudad, pero su posición - y también su propio asentamiento urbano- sería muy diferente, ya que toda la comunidad hebrea sevillana sufrió, de una u otra manera, las duras consecuencias del pogrom, bien fuese la muerte, el destierro o la conversión.

No obstante, hasta que tuvieron lugar los tristes acontecimientos de 1391, la comunidad judía sevillana se fue desarrollando a la par que la cristiana, por lo que, a partir del mismo Repartimiento de Sevilla, se comprueba el importante papel desempeñado por lo que podríamos definir como una élite de poderosos judíos, muy bien relacionados con la corona, con la que colaboraban directamente y de la que, como compensación, obtenían muchos favores, hasta llegar acaparar los principales oficios de la hacienda real castellana, por lo menos desde el reinado de Alfonso X hasta, incluso, el gobierno de los primeros Trastámara.

Así pues, ni siquiera el ascenso al trono de la nueva dinastía que, al menos en teoría, pretendía eliminar la alta posición que ciertos hebreos habían disfrutado, desde un principio, a la sombra de la corona, impidió que algunos de ellos siguieran ejerciendo las misma funciones que en épocas anteriores,

Habría de ser pues, durante el gobierno de los primeros Trastámara, que vino a coincidir con los terribles sucesos de 1391, cuando, en lo relativo a Sevilla, ciudad originaria de la nueva dinastía, intentaron imponerse las nuevas líneas de actuación definidas por la corona, que, por lo menos en el plano teórico, habrían supuesto una actitud diferente con relación a los hebreos, cuyo cambio más visible 
sería el relevo de los judíos, en gran parte de sus tradicionales ocupaciones, por los conversos, según podemos comprobar concretamente en el contexto sevillano.

Entre todas estas funciones, debemos destacar la de Almojarife o Tesorero Mayor, el cargo financiero de mayor confianza del monarca que, al parecer, ya existía en época de Alfonso VIII con la primera denominación y fue en tiempos de Alfonso X cuando empezó a utilizarse la de Tesorero Mayor del Rey, título y cargo que iría perdiendo importancia con Enrique II de Trastámara, que lo sustituiría por tesoreros y recaudadores parciales, dependientes de los Contadores, oficio que habría de adquirir una importancia de primer orden a partir de entonces, hasta llegar a convertirse la Contaduría Mayor de Hacienda, de la que dependía la Contaduría Mayor de Cuentas, en el principal órgano gestor de la Hacienda regia, dirigido por los Contadores Mayores, cuyas noticias más antiguas provienen del reinado de Pedro I, aunque terminarían por consolidarse con los primeros Trastámaras, en el transito del siglo XIV al siglo XV1.

Por tanto, el objetivo concreto de nuestro trabajo no es otro que aproximarnos al conocimiento de uno de estos conversos sevillanos: Nicolás Martínez de Medina que, en los últimos años de su vida, también aparece con el nombre de Nicolás Martínez de Sevilla, cuya actuación pública se desarrolló durante los reinados y a la sombra de los primeros Trastámara, desde Enrique II (1369-1379) hasta Juan II (1406-1454) y que, tras una brillante carrera en Sevilla y en la corte, llegaría a ser contador mayor de Castilla y al que podemos, una vez más, tomar como ejemplo de estos ilustres judíos y conversos sevillanos, que, a lo largo de la baja Edad Media, desempeñaron un papel de primer orden en la sociedad sevillana y castellana de la época².

Con este fin, nos referiremos, primero, a su entorno familiar, para después acercarnos a su proyección pública en Sevilla y en la corte castellana.

\section{EL ÁMBITO PRIVADO: LA FAMILIA DE NICOLÁS MARTÍNEZ DE MEDINA}

El linaje de los Medina sevillanos estaba constituido, al menos, por dos ramas principales: una descendiente de Ruy González de Medina, que se estableció en Sevilla a raíz de la conquista y la segunda, de la que no se tienen noticias hasta mitad del siglo XIV, cuando se avecindó en la ciudad el primer Martín Martínez de

1 LADERO QUESADA, M. A.: La Hacienda Real de Castilla en el siglo XV, Universidad de La Laguna, 1973, pp. 17-22 y Fiscalidad y poder real en Castilla (1252-1269), Madrid, 1993, pp. 234-239.

2 MONTES ROMERO-CAMACHO, I: «Juan Sánchez de Sevilla, antes Samuel Abravanel. Un modelo de converso sevillano anterior al asalto de la Judería de 1391. Datos para una biografía», Aragón en la Edad Media, Homenaje a la profesora Carmen Orcástegui Gros, n.ํ XIV-XV, Zaragoza, 1999, pp. 10991113. «El judío sevillano don Yusaph Pichón, contador mayor de Enrique II de Castilla (1369-1379)». Judaísmo hispano: Estudios en memoria de José Luis Lacave Riaño, II, Madrid, 2002, pp. 561-574. «Judíos y conversos sevillanos en la hacienda real de Castilla: de Alfonso X a los primeros Trastámara. Una aproximación prosopográfica», en Agentes de los sistemas fiscales en Andalucía y los reinos hispánicos (siglos XIII-XVIII), a publicar por el Instituto de Estudios Fiscales, Madrid, 2014 (en prensa). 
Medina, casado con Constanza Fernández y abuelo de Nicolás Martínez de Medina. Fue el gran analista sevillano del siglo XVII, don Diego Ortiz de Zúñiga quien aclaró los orígenes genealógicos de esta segunda rama de los Medina sevillanos, de los que nacería la casa de Bobadilla, haciéndolos proceder de Medina del Campo. Entre sus parientes se contaban don Lope de Barrientos, obispo de Cuenca, quien apoyaría la fundación del convento de San Jerónimo de Buenavista, así como el cardenal don Juan Tavera, descendiente, por línea materna, de los Medina de Medina del Campo ${ }^{3}$. Entre las señas de identidad del linaje está su indudable origen converso ${ }^{4}$, aunque, en opinión de Rafael Sánchez Saus, habría sido una familia protoconversa, por lo que sus orígenes judaicos, aparte de poco explícitos, eran muy antiguos a finales del siglo XIV y principios del siglo XV, cuando el linaje alcanza su máximo encumbramiento en la generación encabezada por Nicolás Martínez de Medina, fiel servidor de la corona, vasallo de los reyes, último tesorero mayor de Andalucía, tesorero mayor del pedido en los reinos de Toledo, Andalucía y Murcia, contador mayor de cuentas, durante la minoría de Juan II, contador mayor de Castilla y miembro del Consejo Real, además de uno de los principales integrantes del cabildo sevillano en el primer tercio del siglo XV5.

Nicolás Martínez de Medina era hijo del segundo Martín Martínez de Medina, veinticuatro de Sevilla, y de Juana Fernández Carrillo. Contrajo matrimonio con Beatriz López de las Roelas, de ascendencia toledana e hija de Lope Pérez de las Roelas, una de cuyas ramas también se establecería en Sevilla, dando lugar al linaje Jaén, asimismo converso ${ }^{6}$.

El matrimonio formado por Nicolás Martínez de Medina y Beatriz López de las Roelas tuvo amplia descendencia, constituida, al menos, por dos hijos varones —Diego y Juan- y por seis hijas: Juana, la única que, al parecer, permaneció soltera, Inés, Constanza, Leonor, Beatriz e Isabel.

Entre sus descendientes varones destaca su hijo mayor, Diego, monje jerónimo, mientras que de su segundo hijo, Juan, sólo hay algunas pocas noticias hasta 1413, por lo que pudo morir por entonces, más de veinte años antes que su padre, terminando con él la línea masculina de esta rama de los Medina, ya que no se le conoce descendencia. Según parece y como era previsible, Juan había iniciado, desde su más temprana juventud, una brillante carrera, tanto en la corte, como

${ }^{3}$ ORTIZ DE ZÚÑIGA, D.: Discurso genealógico de los Ortices de Sevilla, Madrid, 1929, pp. 49-51.

${ }^{4}$ LADERO QUESADA, M. A.: Historia de Sevilla, II. La ciudad medieval. Sevilla, 1989 (3. a ed.), p. 155.

5 ORTIZ DE ZÚÑIGA, D.: Anales eclesiásticos y seculares de la Muy Noble y Muy Leal ciudad de Sevilla, Sevilla, 1988, vol. 2, pp. 104, 271, 319, 330, 332, 335, 336, 345, 346, 349, 350, 392, 396, 398 , 405, 444. SÁNCHEZ SAUS, R.: Linajes sevillanos medievales, Sevilla, 1991, I, pp. 180 y ss. SÁNCHEZ SAUS, R.: Las élites políticas bajo los Trastámara. Poder y Sociedad en la Sevilla del siglo XIV, Sevilla, 2009, pp. 113, 128. GIL FERNÁNDEZ, J.: Los conversos y la Inquisición sevillana, vol. IV, Sevilla, 2001, pp. $444-445$.

${ }^{6}$ SÁNCHEZ SAUS, R.: Linajes sevillanos medievales..., I, p. 139. 
vasallo de Juan $\mathrm{II}^{7}$, como en el concejo sevillano, donde, contando, una vez más, con el favor real, había sido elegido como mayordomo hijosdalgo del concejo ${ }^{8}$.

Diego Martínez de Medina, nacido en Sevilla en torno a 1375, era hijo de Nicolás Martínez de Medina y de Beatriz López de las Roelas. En sus años juveniles cultivó la poesía y llegó a ser veinticuatro de Sevilla, gracias a sus grandes dotes intelectuales y su extraordinaria posición social, que le auguraban un brillante futuro en el mundo, al que renunció para profesar como fraile jerónimo en Guadalupe.

En torno a 1413, dejó provisionalmente el monasterio, con el fin de, en opinión de Mario Méndez Bejarano, ocuparse de los asuntos familiares en Sevilla, junto a su madre, durante las largas permanencias en la corte de don Nicolás, dada su magnífica preparación jurídica, ya que era doctor en ambos Derechos, civil y canónico ${ }^{9}$, coincidiendo precisamente con el último año en que está documentado su hermano Juan, por lo que, seguramente, su fallecimiento justificaría el regreso a Sevilla de fray Diego. Posiblemente, sería durante su permanencia en la ciudad cuando, asistido por otros dos frailes, uno de los cuales, Juan de Medina, también era, además de su pariente, sevillano, pudo iniciar los trámites para la fundación del futuro convento de San Jerónimo de Buenavista ${ }^{10}$, para lo que, desde un primer momento, habría de contar con el apoyo incondicional, moral y económico, de sus padres, Nicolás Martínez de Medina y Beatriz López de las Roelas, así como con el favor del arzobispo don Alonso de Exea, todo lo cual hizo posible que, muy pronto, el 27 de enero de 1414, los jerónimos se apoderaran de la heredad de Mazuelos o Buenavista, al tiempo que se constituyó una incipiente comunidad, que eligió a fray Diego como prior, aprobada por el Capitulo General de la orden en 1425. Cuando, al poco tiempo, falleció su madre, fray Diego pidió permiso a los papas Martín V y Eugenio IV, con el fin de aplicar e incorporar la legítima y el res-

7 En 1408, el rey otorgaba Johan Martínez, hijo de Nicolás Martínez, su contador mayor de las cuentas, 1.900 maravedíes por su tierra, merced que le fue acrecentada en 4.500 maravedíes más por su tierra, para tres lanzas, a los que se añadieron otros 3.000 maravedíes que le habían sido concedidos al jurado Alfonso Fernández, para dos lanzas, difunto, por lo que en adelante, Johan Martínez cobraría de la corona 7.500 maravedíes, para cinco lanzas, aunque de los 3.000 maravedíes acrecentados sólo percibió este año 2.125 maravedíes, desde el 15 de abril hasta el 31 de diciembre. En 1409 se le libraron otros 4.500 maravedíes de su tierra, para tres lanzas (VILAPLANA MONTES, M. a A: «Un ajuste de cuentas del alcabalero mayor de Sevilla Pedro Ortiz (1420)", Historia. Instituciones. Documentos, 1 (1974), pp. 419-501, vid. pp. 451, 455).

${ }^{8}$ El 8 de julio de 1412, desde Cuenca, Juan II escribía al concejo de Sevilla, confirmando la designación hecha por la ciudad del mayordomo hijosdalgo a Juan Martínez, hijo del tesorero Nicolás Martínez de Sevilla, y de mayordomo ciudadano a Alfonso Fernández, hijo de Alfonso Fernández del Marmolejo, para el año 1412 a 1413, en sustitución de Miçer Venturín Venzón y Francisco Fernández del Marmolejo, que habían sido mayordomos hijosdalgo y ciudadano, respectivamente, en el año 1411 a 1412, terminando el desempeño de su cargo el día de San Juan de este último (Archivo Municipal de Sevilla (AMS), Papeles de Mayordomazgo, 1412, doc. n. 9. COLLANTES DE TERÁN, F.: Inventario de los Papeles del Mayordomazgo del siglo XV, tomo I: 1401-1416, Sevilla, Excmo. Ayuntamiento de Sevilla, 1972, p. 397).

9 MÉNDEZ BEJARANO, M.: Diccionario de Escritores, Maestros y Oradores naturales de Sevilla y su actual provincia, 3 vols. Sevilla, 1922-1925, II, p. 41.

10 ORTIZ DE ZÚÑIGA, D.: Anales..., 2, pp. 271, 272, 335, 346, 348, 349, 376, 383, 384, 392, $397,398$. 
to de su herencia a la construcción del monasterio, lo que desencadenaría un pleito entre la comunidad sevillana y la de Guadalupe.

Según parece, en torno a 1430, fray Diego debió ocuparse de ejecutar el testamento de su madre, como albacea, por lo que hubo de traspasar el priorato del recién fundado monasterio, aunque volvió a ser elegido prior en 1433.

Un año más tarde, en 1434, fallecía su padre en Medina del Campo, lo que hizo posible la culminación de la construcción del monasterio, ya que fray Diego le aplicó el quinto de su herencia, constituido por tierras, casas y otras propiedades y calculado en 6.659 doblas y dos tomines.

También por estos años, fray Diego llegó a un acuerdo con el monasterio de Guadalupe, que le exigía el pago de 102.000 maravedíes y su magnífica biblioteca ${ }^{11}$.

A su muerte, ocurrida en Sevilla en 1446, fue enterrado junto a su padre en la capilla de Santiago de la catedral de Sevilla, algo inexplicable para Ortiz de Zúñiga, que no entendía cuál pudiese ser la causa, pues cuando murió ya su convento tenía iglesia propia y había en ella otros tres altares ${ }^{12}$.

Entre sus obras, son muy conocidos sus versos de consultas teológicas, recogidos en el Cancionero de Baena, como miembro de la escuela alegórica ${ }^{13}$.

En cuanto a las vinculaciones familiares, Nicolás Martínez de Medina consiguió establecer alianzas matrimoniales con las principales familias de la oligarquía sevillana, casando primero a sus hermanas con los linajes Ortiz y Esquivel y, más tarde, a sus hijas con los Cerón, Marmolejo, Melgarejo, Mendoza y Tello, con lo que puede decirse que esta rama de los Medina estaría emparentada y sería antecesora, según Diego Ortiz de Zúñiga, de toda la nobleza ciudadana de Sevilla y de gran parte de Andalucía ${ }^{14}$.

En este caso, como hemos dicho, las estrategias nupciales de la familia tuvieron como protagonistas a las mujeres, ya que de los dos únicos hijos varones de Nicolás Martínez de Medina, uno, Diego, fue monje jerónimo y el otro, Juan, murió muy joven.

De sus cinco hijas, sólo una, Juana Fernández Carrillo, permaneció soltera, mientras que, de sus cinco hermanas, Constanza Martínez Carrillo fue mujer de Juan Cerón, Leonor Martínez de Medina contrajo matrimonio con Luis Fernández Marmolejo, Beatriz López de las Roelas tomó por esposo a Pedro Melgarejo, Isabel de las Roelas fue la segunda esposa de Ruy Díaz de Mendoza, «el Calvo» e Inés Martínez de Medina casó con Juan Gutiérrez Tello.

11 MÉNDEZ BEJARANO, M.: Diccionario..., II, p. 41.

12 ORTIZ DE ZÚÑIGA, D.: Anales..., 2, pp. 271, 392.

13 MÉNDEZ BEJARANO, M.: Diccionario..., II, p. 41.

14 SÁNCHEZ SAUS, R.: Linajes sevillanos medievales..., I, pp. 180-182. ORTIZ DE ZÚÑIGA, D.: Anales...,2, pp. 335 y 396. 
Por su parte, de las dos hermanas de Nicolás Martínez de Medina, María González de Mendoza fue esposa de Diego Ortiz y Beatriz Martínez de Medina de Pedro Rodríguez de Esquivel.

Diego Ortiz fue enriquista y vasallo de Juan I y Enrique III. En 1375 contrajo matrimonio con María González de Mendoza, hija del potentado veinticuatro sevillano Martín Martínez de Medina y de su mujer, Juana Fernández Carrillo, y hermana, por tanto, de Nicolás Martínez de Medina. Sus hijos, Pedro y Diego, se criaron en la casa del condestable don Ruy López Dávalos, en Úbeda, a quien siempre sirvieron y lo que, junto a su parentesco con Nicolás Martínez de Medina, favoreció su carrera política y financiera en Sevilla y en la corte ${ }^{15}$. Pedro fue recaudador mayor de las rentas reales y administrador del almojarifazgo real de Sevilla. Se inició en la política urbana como jurado, para después ser veinticuatro, fiel ejecutor y contador mayor de Sevilla, al suceder a su cuñado Ruy López. Tomó parte en las luchas de bandos, siguiendo, junto a su hermano Diego, a su tío materno, Nicolás Martínez de Medina, que había tomado partido por Ortún Velázquez para corregidor de Sevilla y, por tanto, por los Stúñiga, en contra del almirante Alonso Enríquez. Como hemos dicho, ambos hermanos, Diego y Pedro, eran criados de Ruy López Dávalos, uno de los mejores aliados del Justicia Mayor Diego López de Stúñiga, que encabezaba uno de los principales grupos de poder de la corte. Igualmente, Diego, casado con Beatriz Fernández Marmolejo, hija de Alonso Fernández Marmolejo y Juana Dorta, prima segunda, por tanto, de Luis Fernández Marmolejo, junto a su hermano y Luis Fernández Marmolejo, tomó parte en numerosas operaciones y cargos financieros, gracias a la posición alcanzada por su tío Nicolás Martínez de Medina ${ }^{16}$.

Al igual que los Medina, el linaje de los Esquivel constaba de dos ramas, una que, procedente de Vizcaya, habría acompañado a San Fernando en la conquista de Sevilla y que eran parientes de los de Baeza y otra que, en opinión de Ortiz de Zúñiga, estuvieron avecindados en Sevilla y Alcalá de Guadaira y que, por lo que parece, no eran limpios de sangre, por lo que su ascendencia difícilmente podría reconocerse con claridad antes de mitad del siglo XIV ${ }^{17}$.

Pedro Rodríguez de Esquivel era hijo primogénito de Ruy Pérez de Esquivel y de Estefanía Alonso Carrillo, siendo su padre uno de los principales aliados sevillanos de Enrique II de Trastámara, al que acompañó en su entrada en la ciudad después de la victoria de Montiel, ya que, al parecer, había tenido que exiliarse de Sevilla ${ }^{18}$. A partir de entonces, Ruy Pérez de Esquivel siempre permaneció fiel a la nueva dinastía y gozó de la confianza de los reyes, elevada posición que le permitió,

15 ORTIZ DE ZÚÑIGA, D.: Anales..., 2, p. 332.

${ }^{16}$ SÁNCHEZ SAUS, R.: Linajes sevillanos medievales..., I, pp. 217-221. ORTIZ DE ZÚÑIGA, D.: Anales..., 2, p. 332.

17 SÁNCHEZ SAUS, R.: Linajes sevillanos medievales..., I, p. 98. SÁNCHEZ SAUS, R.: Las élites políticas bajo los Trastámara..., p. 59.

18 ORTIZ DE ZÚÑNIGA, D.: Anales...,. 2, p. 210. 
entre otras cosas, incrementar su patrimonio con la compra, el 30 de octubre de 1377, del lugar de El Coronil, a los herederos de don Martín Fernández de Guzmán, señor de Orgaz, a quien, según la carta de compra, Ruy Pérez había prestado innumerables servicios, por 12.000 mrs. ${ }^{19}$, propiedad colindante con el donadío de Los Santos, que previamente Ruy Pérez había adquirido de Juan Martínez, jurado de la Magdalena, lo que deja entrever la clara intención, por parte de Ruy Pérez, como la de muchos otros personajes emergentes de la nueva oligarquía conversa sevillana, forjada al calor de la recién instaurada dinastía Trastámara, de labrarse un importante patrimonio en la frontera granadina. Pocos años más tarde, el 25 de abril de 1381, Juan I concedía carta de privilegio a Ruy Pérez, su vasallo, para los pobladores de El Coronil, con la condición de que se asentasen «en el vuestro castillo del Coronil que vos agora labrades en la campiña de Sevilla» ${ }^{20}$, patrimonio que se vio acrecentado con la adquisición de la torre fuerte de La Serrezuela, próxima a Dos Hermanas ${ }^{21}$. Paralelamente a la constitución de su señorío, Ruy Pérez continuaba desempeñando importantes cargos al servicio de la corona, especialmente en cuestiones financieras, pues, según Ortiz de Zúñiga, en 1378 aparece ya como tesorero mayor de Andalucía ${ }^{22}$ y en 1379 se le menciona como uno de los contadores mayores de la Casa de Cuentas, cuyo cometido era fiscalizar los ingresos y gastos de la hacienda real ${ }^{23}$, así como en el concejo sevillano, donde llegó a ser veinticuatro, constatándosele en este cargo al menos desde 1381, mayordomo y alcalde mayor de la ciudad desde 1385, año en que también fue procurador de Sevilla en las Cortes de Valladolid, donde Juan I lo distinguió como uno de los cuatro ciudadanos que habrían de constituir la tercera parte de los doce miembros del Consejo Real. Sin duda, fue por estos años cuando la carrera política de Ruy Pérez alcanzó su punto culminante, por más que también se ha dicho que llegó a ser adelantado mayor de la frontera, aunque sin mucho fundamento y tal vez confundiéndosele con su hijo, Pedro Rodríguez de Esquivel, por lo que Rafael Sánchez Saus se inclina más a que pudiera haber desempeñado, en todo caso, la lugartenencia, en algunas ocasiones, y consejero de Enrique III $^{24}$. Como alcalde mayor de Sevilla, una de sus acciones más memorables y la última de sus actuaciones públicas de la que tenemos noticia, fue, sin duda, su fallido intento de impedir el asalto a la judería de Sevilla, en $1391^{25}$ Contrajo matrimonio con Estefanía Alonso Carrillo, de la que no conocemos su pro-

19 ORTIZ DE ZÚÑIGA, D.: Discurso..., p. 81 y SALAZAR Y CASTRO, L.: Historia Genealógica de la Casa de Haro. Ed. de Dalmiro de la Válgoma y Díaz Varela, Madrid, 1959, p. 124.

20 GONZÁLEZ JIMÉNEZ, M.: La repoblación de la zona de Sevilla durante el siglo XIV, Sevilla, 1993 (2. ${ }^{\text {a }}$ ed.), pp. 84-85.

21 ORTIZ DE ZÚÑIGA, D.: Discurso..., p. 84.

22 ORTIZ DE ZÚÑIGA, D.: Anales..., vol. 2, p. 395.

${ }^{23}$ VALDEÓN BARUQUE, J.: Enrique I/ (1369-1379), Palencia, 1996, p. 188.

24 AMS, Papeles de Mayordomazgo, 1384-1386, docs. n.os 54, 133. COLLANTES DE TERÁN DELORME, F.: Inventario de los Papeles de Mayordomazgo del siglo XIV..., pp. 31, 46. ORTIZ DE ZÚÑIGA D.: Anales..., 2, p. 259. ORTIZ DE ZÚÑIGA, D.: Discurso..., p. 81. GONZÁLEZ JIMÉNEZ, M.: La repoblación de la zona de Sevilla durante el siglo XIV..., pp. 84-85. SÁNCHEZ SAUS, R.: Las élites políticas bajo los Trastámara..., pp. 59-61.

25 ORTIZ DE ZÚÑIGA, D.: Anales..., 2, p. 236. 
cedencia, aunque no parece que sea sevillana, con la que tuvo numerosa descendencia, la mayor parte de ella con amplio protagonismo en el ámbito sevillano, lo que hizo del linaje Esquivel uno de los más característicos de la oligarquía hispalense del siglo XV.

Entre todos los hijos de Ruy Pérez de Esquivel y de Estefanía Alonso Carrillo hay que destacar a Pedro Rodríguez de Esquivel, su primogénito, por lo que, como tal, heredó el señorío de El Coronil y La Serrezuela ${ }^{26}$. Siguiendo la estela marcada por su padre, desde muy joven, desempeñó importantes funciones, tanto en el ámbito local, como en relación a la corona, distinguiéndose como uno de los miembros más versátiles de la emergente élite política sevillana, en el tránsito del siglo XIV al siglo XV. Veinticuatro de Sevilla, al menos desde 1385, pasó a ostentar la mayordomía de la ciudad durante el período de 1386-1387 y en 1388 actuaba como lugarteniente del adelantado mayor de la frontera, por entonces el conde de Niebla, mientras que en años posteriores, en 1394 y en 1398, continuó ejerciendo otros oficios y funciones militares en la frontera granadina, como en 1394, cuando, al mando de otros caballeros, defendía el sector fronterizo con Granada correspondiente al concejo de El Coronil o cuando, en 1398, fue nombrado primer alcaide de la estratégica fortaleza de Utrera, una vez repoblada tras haber sido totalmente destruida por los musulmanes ${ }^{27}$. Entre julio de 1397 y agosto de 1400 actuó como recaudador de las imposiciones de Sevilla, mientras que ya en los primeros años del siglo XV volvió a ocupar el mayordomazgo de la ciudad en 1408-1409, al tiempo que, en repetidas ocasiones, defendió los intereses del concejo sevillano en la corte y, en 1410, junto a Nicolás Martínez de Medina, representó a Sevilla, como procurador, en la Junta que Juan II mandó hacer en Córdoba, bajo la presidencia de su tío y regente, el infante don Fernando, para decidir importantes asuntos concernientes a la corona de Castilla, entre los que destacaba la organización de una nueva campaña contra Granada, que culminaría con la conquista de Antequera $^{28}$. Por lo que sabemos, Pedro Rodríguez de Esquivel habría sido uno de los miembros destacados de la oligarquía sevillana que procuraron atenuar, en lo posible, las consecuencias negativas derivadas de la suspensión del concejo sevillano por parte de Enrique III, que prohibió el ejercicio de los oficios de regidores y alcaldes mayores, por lo que, aunque hubo conformarse con ser jurado de Santa Catalina, continuó participando en el gobierno de la ciudad hasta que en 1407 los oficiales depuestos consiguieron de la corona ser restituidos en sus $\operatorname{cargos}^{29}$.

${ }^{26}$ SÁNCHEZ SAUS, R.: Linajes sevillanos medievales..., I, pp. XXXII-II, 97, 161, 175. SÁNCHEZ SAUS, R.: Las élites políticas bajo los Trastámara..., pp. 96-97.

${ }^{27}$ AMS, Papeles de Mayordomazgo, 1393-1395, doc. ․ํ 3. COLLANTES DE TERÁN DELORME, F.: Inventario de los Papeles de Mayordomazgo del siglo XIV..., pp. 75-76.

${ }^{28}$ AMS, Papeles de Mayordomazgo, 1396-1400, doc. n.. 8. COLLANTES DE TERÁN DELORME, F.: Inventario de los Papeles de Mayordomazgo del siglo XIV..., p. 80. AMS, Papeles de Mayordomazgo, 1406, doc. n.. 128; 1409, doc. n. 95 y 1411, doc. n. 41. COLLANTES DE TERÁN DELORME, F.: Inventario de los Papeles del Mayordomazgo del siglo XV, tomo I: 1401-1416..., pp. 175, 303, 371.

29 ORTIZ DE ZÚÑIGA, D.: Anales..., 2, p. 307. 
Contrajo matrimonio, como sabemos, con Beatriz Martínez de Medina, hija del veinticuatro Martín Martínez de Medina y hermana de Nicolás Martínez de Medina. En 1414, hizo testamento y fundó mayorazgo en la persona de su hijo Fernán Rodríguez de Esquivel, con El Coronil y la heredad de La Serrezuela, ambos en la Campiña sevillana ${ }^{30}$.

Juan Cerón, era hijo primogénito de Martín (I) Fernández Cerón y de Leonor Sánchez de Mendoza, siento el primer titular del mayorazgo fundado por su padre, quien consiguió afianzar la posición del linaje en la oligarquía ciudadana de SeviIla, gracias a su enriquecimiento y al ejercicio de cargos públicos, ambas cosas propiciadas por su fidelidad a importantes miembros de la corte, caso del infante don Fernando y, más tarde, de sus hijos, los Infantes de Aragón. Heredó de su padre, Martín Fernández Cerón, la hacienda de Merlina, cuya fertilidad y amenidad justificaron que, en 1407, el infante don Fernando (de Antequera) la escogiera para recuperarse de una grave enfermedad. Fue vasallo del rey, alcaide de los alcázares de Sevilla y alcalde mayor de la ciudad, desde 1412, haciéndose visible, también por estos años, su presencia en la corte, como procurador de Sevilla. Por su condición de alcalde mayor tuvo un papel relevante en las luchas de bando que ensangrentaron Sevilla en 1416, por lo que, desde 1417 hasta 1419, fue condenado a prisión. Una vez reintegrado en sus cargos, volvió a recuperar la alcaldía mayor, oficio que ostentó hasta su muerte, en 1450. Casó con Constanza Martínez Carrillo, hija de Nicolás Martínez de Medina y de Beatriz López de las Roelas ${ }^{31}$.

Luis Fernández Marmolejo, de clara ascendencia conversa, era hijo de Francisco Fernández Marmolejo, contador mayor de Juan I entre 1379 y 1390, y de Inés Martel, siendo heredado con extensas propiedades en Almensilla, localidad ubicada en el Aljarafe sevillano y patrimonio principal del futuro mayorazgo de esta rama del linaje, que, aunque en un principio fueron partidarios de Pedro I, más tarde abrazaron la causa enriquista, por lo que, tras la subida al trono de la dinastía Trastámara, a la que siempre se mantuvieron fieles, obtuvieron grandes compensaciones económicas e importantes cargos en el concejo sevillano y en la misma corte, al tiempo que, mediante alianzas matrimoniales, se vincularon a las principales familias de la oligarquía local. Según parece, la carrera política de Francisco Fernández Marmolejo empezó muy pronto, en 1379, como jurado de Sevilla. En 1387 era ya veinticuatro y ocupaba una de las mayordomías sevillanas, al menos desde 1388, cargo que volvería a desempeñar en ejercicios posteriores, como en $1398-1399$ y en 1410 y $1411-1412^{32}$, mientras que en 1414 no quiso acep-

30 SÁNCHEZ SAUS, R.: Linajes sevillanos medievales..., I, pp. XXXII-II, 97, 161, 175. SÁNCHEZ SAUS, R.: Las élites políticas bajo los Trastámara..., pp. 96-97.

31 ORTIZ DE ZÚNIIGA, D.: Anales..., 2, pp. 331, 373, 397. SÁNCHEZ SAUS, R.: Linajes sevillanos medievales, , I, XXVI-II, pp. 80, 81, 105, 175, 282.

32 AMS, Papeles de Mayordomazgo, 1386-1396: Labores en los castillos, docs. n.os 9, 11, 19, 26; 1387-1388, doc. n. $\div$ 40. COLLANTES DE TERÁN DELORME, F.: Inventario de los Papeles de Mayordomazgo del siglo XIV..., pp. 70, 99, 100, 101 y 102. AMS, Papeles de Mayordomazgo, 1400-1401, doc.

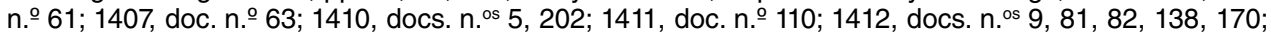


tar el oficio, a pesar de haber sido propuesto por el rey ${ }^{33}$. En 1396, año en que Enrique III inhabilitó el concejo sevillano, sería elegido por el rey como uno de los fieles ejecutores que puso en Sevilla. Francisco Fernández del Marmolejo se dedicó, igualmente, al arrendamiento de rentas reales, actuando como socio de su primo, Alonso Fernández de Marmolejo y de Nicolás Martínez de Medina, con el que emparentó en 1410, mediante el matrimonio de su hijo Luis con Leonor Martínez de Medina. Entre 1407 y 1410, Luis empezó a colaborar con Nicolás Martínez de Medina, al igual que antes lo hiciera su padre, como recaudador del pedido y las monedas de 1407-1408 y 1409 en el arzobispado de Sevilla y obispado de Cádiz, junto a su sobrino, Diego Ortiz. Cuando, en 1410, se convierte en su yerno, Luis aparece ya sólo como recaudador. Tomó parte, siendo ya veinticuatro, en las luchas políticas que desestabilizaron el concejo sevillano entre 1416 y 1420, por lo que fue encarcelado entre 1417 y 1419 , y condenado a dieciséis meses de destierro en 1420. Como es sabido, contrajo matrimonio con Leonor Martínez de Medina, hija de Nicolás Martínez de Medina y de Beatriz López de las Roelas, con la que, según Diego Ortiz de Zúñiga, tuvo muchos e ilustres hijos, entre otros, Francisco Fernández del Marmolejo, de quien procede la casa primera, Nicolás Martínez del Marmolejo, canónigo, arcediano de Écija, gobernador y vicario general del arzobispado de Sevilla, Diego Fernández del Marmolejo, canónigo y fundador de la capilla de su linaje en la catedral, Juan Fernández del Marmolejo, progenitor de los Marmolejo de Abreu... Luis Fernández del Marmolejo debió morir, como su suegro, en torno a 1434, año en que se llevó a cabo la partición de sus bienes ${ }^{34}$.

Pedro Melgarejo, veinticuatro de Sevilla y fiel ejecutor del concejo, casó con Beatriz López de las Roelas, hija de Nicolás Martínez de Medina, muriendo en 1452. Al igual que ocurrió con otros linajes vinculados familiarmente con Nicolás Martínez de Medina, los Melgarejo, afianzados en la oligarquía sevillana en el tránsito del siglo XIV al siglo XV, debieron su fortuna económica y política, entre otras cosas, a su proximidad con el infante don Fernando, manteniendo su fidelidad a los Infantes de Aragón ${ }^{35}$.

Ruy Díaz de Mendoza,»el Calvo», era hijo de Juan Fernández de Mendoza y de Inés Melgarejo. En su primera juventud, fue criado del maestre de Santiago, don Lorenzo Suárez de Figueroa, combatiendo a su lado en las campañas granadinas, a partir de la conquista de Zahara, en 1407, lo que le vincularía para siempre al infante don Fernando y, más tarde, a sus hijos. Esta inquebrantable fideli-

1413, doc. n.ำ 16. COLLANTES DE TERÁN DELORME, F.: Inventario de los Papeles del Mayordomazgo del siglo XV, tomo I: 1401-1416..., pp. 92, 216, 316, 358, 385, 397, 411, 412, 425, 426, 433, 434, 447, 448 COLLANTES DE TERÁN, A: «La élite financiera en la Sevilla bajomedieval: los mayordomos del concejo", Revista d'Historia Medieval, 11 (2000), pp. 13-40, vid. p. 34.

${ }_{33}$ AMS, Papeles de Mayordomazgo, 1414, doc. n. 5. COLLANTES DE TERÁN DELORME, F.: Inventario de los Papeles del Mayordomazgo del siglo XV, tomo I: 1401-1416..., p. 472.

${ }_{34}$ SÁNCHEZ SAUS, R.: Linajes sevillanos medievales..., I, XLVII-5, pp. 160, 161, 162, 165, 176, 218 , 322. ORTIZ DE ZÚÑIGA, D.: Anales..., 2, pp. 330, 336, 397.

${ }^{35}$ SÁNCHEZ SAUS, R.: Linajes sevillanos medievales, I, LI-4, pp. 36, 95, 164, 176, 180, 184, 188. ORTIZ DE ZÚÑIIGA, D.: Anales..., 2, p. 397. 
dad, le llevó a defender los derechos de su señor a la corona de Aragón, en tierras aragonesas, por lo que, como premio, fue uno de los vasallos castellanos que formó parte de su séquito cuando tomó posesión de dicha corona. A la muerte de don Fernando, se convirtió en uno de los hombres de confianza de su hijo don Juan, que lo nombró su camarero y guarda mayor, desempeñando un papel de primer orden en las guerras civiles que asolaron Castilla, por causa de las ambiciones políticas de los Infantes de Aragón, por lo que la derrota de estos tuvo graves consecuencias económicas y políticas para el linaje Mendoza, aunque no por ello Ruy Díaz de Mendoza abandonó la fidelidad a don Juan de Navarra, llegando a ser apresado junto a su señor en Italia, tras la derrota de Ponza. La lealtad de Ruy Díaz de Mendoza hacia don Juan fue recompensada tras el matrimonio, en 1437, del futuro Enrique IV con doña Blanca de Navarra, hija del infante don Juan, su señor, por lo que sus fieles castellanos fueron rehabilitados en sus bienes y oficios. Al parecer, contrajo matrimonio con Beatriz de Guzmán, hija de don Alvar Pérez de Guzmán y de doña Beatriz de Silva, de la que, según Ortiz de Zúñiga, no tuvo hijos, y también casó con Isabel de las Roelas, hija del tesorero Nicolás Martínez de Medina, quien, al morir Ruy Díaz de Mendoza sin hijos, heredó los bienes de su marido, a su muerte en $1451^{36}$.

El linaje de los Tello, aunque en principio petrista, fue perdonado por Enrique II, cuando subió al trono, por más que su inquebrantable fidelidad a Pedro I les perjudicó gravemente, ya que vieron truncada su imparable carrera, comenzada en el reinado de Alfonso XI y continuada en el de su hijo legítimo don Pedro. Tras obtener el perdón de don Enrique, uno de sus miembros, Juan Gutiérrez Tello dio comienzo a la rehabilitación del linaje, que, aunque con un protagonismo mucho menor que el de sus antepasados, volvió a recuperar parte de su posición económica y política dentro de la oligarquía sevillana, entre otras cosas, gracias a convenientes uniones matrimoniales, como la del mismo Juan Gutiérrez Tello, lugarteniente del alguacil mayor de Sevilla, con Inés Martínez de Medina o de las Roelas, hija de Nicolás Martínez de Medina ${ }^{37}$.

Entre los parientes más notables de Nicolás Martínez de Medina, muchos de los cuales fueron veinticuatros, alcaldes mayores o mayordomos del concejo, como hemos visto, debemos citar también, entre otros, a Bartolomé Martínez, veinticuatro, alcaide de las Atarazanas y alcalde mayor durante el reinado de Pedro I, aunque según Rafael Sánchez Saus era enriquista, por lo que hubo de exiliarse de Sevilla, a la que regresó tras el triunfo de la «revolución Trastámara». Este mismo autor nos

${ }^{36}$ ORTIZ DE ZÚÑIGA, D.: Anales..., 2, pp. 345, 376, 377, 443, 444. SÁNCHEZ SAUS, R.: Linajes sevillanos medievales, I, LII-VI, pp. 112, 176, 192, 195, 196, 203. Ambos autores nos aportan numerosas noticias sobre este personaje muy significado y vinculado, como Nicolás Martínez de Medina y sus parientes, a don Fernando de Antequera y los Infantes de Aragón. No está claro su matrimonio con Isabel de las Roelas, pues, según parece, casó con Beatriz de Guzmán, hija de don Alvar Pérez de Guzmán y de doña Beatriz de Silva, de la que no se le conoce descendencia.

37 SÁNCHEZ SAUS, R.: Linajes sevillanos medievales, I, LXXIV-16, pp. 83, 175, 299, 300. ORTIZ DE ZÚÑIGA, D.: Anales..., pp. 182, 397. 
habla de otro Bartolomé Martínez, tesorero mayor de Andalucía durante el reinado de Juan I, que habría de ser uno de los cinco fieles ejecutores que Enrique III nombró para que ayudasen al corregidor Juan Alonso de Toro, en 1402. Igualmente es digno de mención Fernán Martínez, alcalde mayor en 1380 y, según Rafael Sánchez Saus, en 1386, éste u otro Fernán Martínez de Medina era mayordomo del concejo. Pero, quizá, el más famoso de todos ellos sea el canónigo y arcediano de Écija, en la Iglesia de Sevilla, fundador del Hospital de Santa Marta e inductor ideológico del asalto a la judería de Sevilla de 1391, conocido como Ferrán Martínez que, en opinión de Rafael Sánchez Saus, pudo ser Ferrán Martínez de Medina, cuyo parentesco con Nicolás Martínez de Medina ya defendiera don Diego Ortiz de Zúñiga ${ }^{38}$.

En otro orden de cosas y como tendremos ocasión de ver, la enorme riqueza de Nicolás Martínez de Medina y su brillante actuación política, tanto a nivel local, como en la corte, le hicieron transcender el ámbito sevillano, a pesar de que sus comienzos al servicio de la hacienda real castellana, siempre a la sombra del gran judío sevillano, don Yusaph Pichón, contador mayor de Enrique II, no fueron del todo fáciles. Todavía en vida del primer Trastámara, don Yusaph cayó en desgracia, al ser acusado ante el rey, entre otros por algunos clanes financieros judíos contrarios, que aspiraban a ocupar su alta posición, de malversación de las rentas públicas, arrastrando en su caída a don Nicolás Martínez. Este pudo ser el motivo de que el rey ordenara la incautación de parte de sus bienes sevillanos, entregándolos a don Pedro Fernández de Velasco, su camarero mayor y uno de los principales miembros de la nueva nobleza trastamarista. Como consecuencia de esta decisión regia, a Nicolás Martínez de Medina, por entonces contador de la hacienda real, y a su mujer les fueron confiscadas unas casas con un almacén de aceite en Sevilla, así como las «heredades de pan y vino llevar y molinos» que tenían en Guillena y en Gerena, localidades próximas a Sevilla, «y todas las otras heredades que havían en tierra de Sevilla». La razón que Juan I, quien confirma la decisión de su padre, durante la fiestas de su coronación en Burgos, el 19 de agosto de 1379, aduce para justificar esta apropiación, así como la que se hiciera a don Yusaph de sus bienes en Aznalcázar, distrito del Aljarafe sevillano, era que «...los quales dichos bienes eran del dicho rey, nuestro padre, por razon de algunas quantias de doblas y de maravedís que los dichos Nicolas Martinez... y el dicho don Yuzaf le debían ${ }^{39}$.

Por lo que parece, según Rafael Sánchez Saus, la hacienda Nicolás Martínez de Medina, como consecuencia de este castigo regio, tardó algún tiempo en recu-

${ }^{38}$ SÁNCHEZ SAUS, R.: Linajes sevillanos medievales, I, L-90, 91, 92, 93, pp. 176, 181. ORTIZ DE ZÚÑIGA, D.: Anales..., 2, pp. 229, 230, 236, 272, 296, 396.

${ }_{39}$ Real Academia de la Historia (RAH), Col. Salazar, M-57, fols. 61r.ํ6r.ㅇ según el Archivo del Condestable. BAER, F.: Die Juden im Christlichen Spanien. Erster Teil. Urkunden und Regesten. Berlin 1929/1936, II, Gregg International Publishers Limited England, 1970, doc. n. 223, pp. 218-219. SUÁREZ FERNÁNDEZ, L.: Historia del reinado de Juan I de Castilla, II, Madrid, 1982, doc. n.ำ 72, pp. 83-85 (no transcribe parte del documento). Las vinculaciones familiares sevillanas de don Pedro Fernández de Velasco en SÁNCHEZ SAUS, R.: Linajes sevillanos medievales..., reseña genealógica LXXIX-3, pp. 119, 250, 272, 316. 
perarse, ya que en el padrón sevillano de 1384 se asigna al contador Nicolás Martínez, caballero, vecino de la collación de San Andrés, una cuantía de sólo trescientos maravedís, mucho menor que la de otros caballeros de su misma posición socioeconómica, por más que debamos señalar que en este mismo padrón, mandado elaborar con el fin de recaudar dinero para hacer frente al enorme costo de la guerra de sucesión a la corona de Portugal, aparte de por su posición de caballero, vecino de la collación de San Andrés, también contribuye en el barrio de Génova, de donde seguramente ya era jurado, con un préstamo de dos mil maravedíes $^{40}$.

Como hemos dicho, vivió primero en la collación de San Andrés y más tarde en la collación de San Miguel, casas que, a su muerte, fueron heredadas por su hija, casada con Pedro Melgarejo, y que, posteriormente, constituirían las casas mayores de la rama principal de los Guzmán, la primera familia de la alta nobleza sevillana, en la plaza del Duque ${ }^{41}$.

Llegó a ser muy rico, siendo propietario, como era habitual, de importantes bienes rurales y urbanos. Entre sus propiedades rústicas, merece la pena destacarse el señorío de Gelo y de Castilleja de Talhara. Otro dato que nos puede dar idea de su riqueza es el de que la legítima de su hija, Isabel de las Roelas, estaba constituida, entre otras cosas, por el heredamiento de Majalcófar, que contaba con una extensión aproximada de mil aranzadas de olivar, tierras calmas, granadales, chaparrales, cuatro molinos de aceite y casas ostentosas ${ }^{42}$, mientras que, por su parte, el único hijo varón que le sobrevivió, fray Diego Martínez de Medina, pudo fundar el monasterio de San Jerónimo de Buenavista con su propia legítima, a la que sus padres sumaron el remanente del quinto aplicado a obras pías ${ }^{43}$.

El 31 de agosto de 1434, fray Diego, cumpliendo los deseos de su padre, procedió, a repartir la herencia, conformada, entre otras cosas, por 5.500 doblas en dinero y un buen número de propiedades rústicas y urbanas, por lo que, como primera medida, llevó a cabo el inventario de los bienes para su reparto, del que nos han llegado algunas noticias: Leonor Martínez (de las Roelas), mujer de Luis Fernández del Marmolejo, además de haber recibido 3.700 doblas como dote, heredó ciento siete aranzadas y dos cuartas de olivar en Mairena del Aljarafe y otras ciento siete aranzadas y dos cuartas en Torreblanca; Inés Martínez de Medina, casada con Juan Gutiérrez Tello, llevó de dote 3.260 doblas y recibió en herencia la heredad de Lorete; Beatriz López de las Roelas, esposa de Pedro de Melga-

40 ÁLVAREZ, M., ARIZA, M. y MENDOZA, J.: Un padrón de Sevilla del siglo XIV. Estudio filológico y edición, Sevilla, 2001:

Barrio de Genua. Los que an de prestar. Caualleros: Nicolás Martínez, fijo de Martín Martínez en II U.........II U mrs. (p. 55) y Sant Andrés. Caualleros: Niculás Martínez, contador. Trezientos maravedíes........ CCC mrs. (pp. 119-120). SÁNCHEZ SAUS, R.: Las élites políticas bajo los Trastámara..., pp. 113, 128.

41 ORTIZ DE ZÚÑIGA, D.: Anales..., vol. 2, p. 330.

42 ORTIZ DE ZÚÑIGA, D.: Discurso..., p. 106.

43 ORTIZ DE ZÚÑIIGA, D.: Anales..., vol. 2, p. 449. 
rejo, fue dotada con 3.733 doblas y heredada con la suerte de Cantalobos en Tablantes e Isabel Martínez de las Roelas contrajo matrimonio con Ruy Díaz de Mendoza el Calvo, tocándole en herencia la heredad de Majalcófar ${ }^{44}$.

Incompresiblemente, el tesorero Nicolás Martínez de Sevilla tenía un hermano pobre, Alvar Martínez, que recibía limosna del concejo sevillano, ya que éste tenía obligación de repartir una cantidad anual entre los menesterosos, en cumplimiento de los antiguos ordenamientos otorgados a la ciudad por los reyes ${ }^{45}$.

\section{LA PROYECCIÓN PÚBLICA: EL CURSUS HONORUM DE NICOLÁS MARTÍNEZ DE MEDINA EN SEVILLA Y EN LA CORTE}

Las primeras noticias que nos han llegado sobre la presencia en la corte de Nicolás Martínez de Medina, lo vinculan, como sabemos, al importante judío sevillano y contador mayor de Enrique II de Trastámara, don Yusaph Pichón, con el que muy posiblemente habría entablado relación en Sevilla y estaría a su servicio como uno de los contadores reales. Pero, en este caso, la amistad con don Yusaph habría de resultarle perjudicial, ya que, por lo que parece, pudo verse envuelto en las acusaciones de malversación que fueron lanzadas contra el poderoso judío, entre otros por algunos de sus correligionarios, que aspiraban a hacerse con el control de la hacienda real, todo lo cual provocó su caída en desgracia ante el primer Trastámara, que tanto lo había protegido, incluso antes de su ascenso al trono, aunque, muy pronto, volvería a recuperar su favor, arrastrando en su desdicha a Nicolás Martínez de Medina ${ }^{46}$. Así, el (19) de agosto de 1379, sólo dos días antes de la muerte alevosa de don Yusaph, en Burgos, durante las fiestas de la coronación de Juan I de Castilla, el nuevo rey, mediante su privilegio rodado, confirmaba la merced hecha por su padre, Enrique II, a Pedro Fernández de Velasco, vasallo del rey y su camarero mayor, así como uno de los miembros más significados de la nueva nobleza trastamarista, de importantes bienes en Sevilla y su tierra. Dichos bienes habían sido propiedad tanto de Yusaph Pichón, como del contador Nicolás Martínez de Medina y de su mujer, a quienes se les había privado de unas casas con un almacén de aceite en Sevilla, así como de las «heredades de pan y vino llevar y molinos» que tenían en Guillena y en Gerena, localidades próximas a Sevilla, "y todas las otras heredades que havían en tierra de Sevilla». La razón que Juan I aduce para justificar esta confiscación, así como la que se hiciera a don Yusaph de sus bienes en Aznalcázar, distrito del Aljarafe sevillano,

44 GIL FERNÁNDEZ, J.: Los conversos y la Inquisición sevillana, vol. IV, Sevilla, 2001, pp. 444-445.

45 El 1 de julio de 1412, Sevilla ordenaba a su mayordomo que le librase 1.000 maravedíes para ayu-

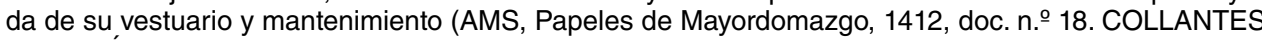
DE TERÁN, F.: Inventario de los Papeles del Mayordomazgo del siglo XV, tomo I: 1401-1416..., p. 398).

${ }^{46}$ MONTES ROMERO-CAMACHO, I.: «El judío sevillano don Yusaph Pichón, contador mayor de Enrique II de Castilla (1369-1379)». Judaísmo hispano: Estudios en memoria de José Luis Lacave Riaño, II, Madrid, 2002, pp. 561-574. 
era que «...los quales dichos bienes eran del dicho rey, nuestro padre, por razon de algunas quantias de doblas y de maravedís que los dichos Nicolas Martinez... y el dicho don Yuzaf le debían» ${ }^{47}$.

En opinión de Rafael Sánchez Saus, los efectos de esta decisión regia todavía se dejaban sentir en el padrón de 1384, donde al contador Nicolás Martínez, caballero vecino de la collación de San Andrés, se le suponía una cuantía de trescientos maravedíes, lo que ciertamente lo encuadraba muy por debajo de otros significados miembros del estamento caballeresco sevillano, aunque debemos tener en cuenta que en este mismo padrón, cuyo principal objetivo era allegar recursos económicos para atender a los grandes gastos que suponía la guerra de sucesión a la corona de Portugal, además de en su condición de caballero, vecino de la collación de San Andrés, también aparece en el Barrio de Génova, del que posiblemente ya era jurado, contribuyendo con un préstamo de dos mil maravedíes ${ }^{48}$.

Por tanto, desde muy pronto, Nicolás Martínez empezó a significarse en el ámbito sevillano, dando comienzo su implicación en la política local, según hemos visto, como jurado del barrio de Génova, auténtico corazón financiero de Sevilla, cargo desde el que cumplió importantes misiones, por delegación de concejo sevillano. A este respecto, los primeros datos que se nos han conservado proceden de 1385 y se refieren también a la guerra de sucesión a la corona de Portugal, que enfrentó a Juan I de Castilla con el maestre de Avis, futuro Juan I de Portugal, en la que, como es sabido, el reino de Sevilla tuvo un papel protagonista ${ }^{49}$. Estos

47 «... Nos el rey, por facer bien y merçed a vos Pedro Fernández de Velasco, nuestro vasallo y nuestro camarero maior, por muchos servicios y buenos que nos havedes fecho y facedes de cada día, damosvos y otrogamosvos y confirmamosvos la merced quel rey don Enrique, nuestro padre, que Dios perdone, vos fizo de las casas con un almazen de azeyte que son en la cibdat de Sevilla que fueron de Nicolás Martínez, contador, y de su muger, y de todas las otras heredades de pan y vino llevar y molinos quel dicho Nicolás Martínez y su mujer havian en Guillena y en Gerena e todas las otras heredades que havían en tierras de Sevilla. Y otrosi vos damos y otorgamos y confirmamos la merced quel dicho rey nuestro padre vos fizo de todos los bienes muebles y raizes que don Yuzaf Picho, judío, vecino de la dicha cibdat de Sevilla, havia en Aznalcazar, logar de la dicha cibdat y en su termino, asi heredades y tierras de pan y olivares y majuelos y viñas y casas y bodegas y tinajas y molinos de azeyte y de pan moler, como de todas las otras cosas qualesquier que el dicho don Yuzaf avia en el dicho logar de Aznalcazar y en sus términos en cualquier manera..., los quales dichos bienes eran del dicho rey, nuestro padre, por razon de algunas quantias de doblas y de maravedis que los dichos Nicolas Martinez... y el dicho don Yuzaf le debían». (RAH, Col. Salazar, M-57, fols. 61r.ํ64r.ำ según el Archivo del Condestable. BAER, F.: Die Juden im Christlichen Spanien. Erster Teil. Urkunden und Regesten. Berlin 1929/1936, II, Gregg International Publishers Limited England, 1970, doc. n.ำ223, pp. 218-219. SUÁREZ FERNÁNDEZ, L.: Historia del reinado de Juan I de Castilla, II, Madrid, 1982, doc. n. 72, pp. 83-85 (no transcribe parte del documento). Las vinculaciones familiares sevillanas de don Pedro Fernández de Velasco en SÁNCHEZ SAUS, R.: Linajes sevillanos medievales, Sevilla, 1991, reseña genealógica LXXIX-3, pp. 119, 250, 272, 316.

48 ÁLVAREZ, M., ARIZA, M. y J. MENDOZA: Un padrón de Sevilla del siglo XIV. Estudio filológico y edición, Sevilla, 2001:

Barrio de Genua. Los que an de prestar. Caualleros: Nicolás Martínez, fijo de Martín Martínez en II U.........II U mrs. (p. 55) y Sant Andrés. Caualleros: Niculás Martínez, contador. Trezientos maravedíes......... CCC mrs. (pp. 119-120). SÁNCHEZ SAUS, R.: Las élites políticas bajo los Trastámara..., pp. 113, 128.

49 MONTES ROMERO-CAMACHO, I.: «Protagonismo sevillano en las aspiraciones de Juan I de Castilla (1379-1390) al trono de Portugal», IV Jornadas Luso-Espanholas de História Medieval: As relaçoes de fronteira no século de Alcanices, Oporto, 1998, vol. I, pp. 411-449. 
documentos nos lo muestran organizando la defensa de la frontera portuguesa ${ }^{50}$ y también recaudando de sus vecinos, como los otros jurados sevillanos y desde su condición de jurado del barrio de Génova, la contribución exigida por la corona para organizar en Sevilla la armada destinada al sitio de Lisboa ${ }^{51}$.

De la misma manera, años más tarde, el jurado Nicolás Martínez, por entonces recaudador y lugarteniente de Ruy González de Medina, mayordomo de Sevilla durante el año fiscal de 1394-1395, se ocupaba de atender a la defensa de la llamada Banda Morisca, es decir, la frontera granadina, en un tiempo que, dada la crisis política vivida por la corona de Castilla durante la minoría de Enrique III, resultaba imprescindible neutralizar la amenaza nazarita ${ }^{52}$.

Será en el reinado efectivo de Enrique III (1395-1406) cuando la carrera política de Nicolás Martínez de Medina alcance sus más altas cotas, que, como tendremos ocasión de ver, se mantendrán durante la minoría de Juan II, dada su estrechísima vinculación con el infante don Fernando y, a su muerte, con sus hijos, los llamados Infantes de Aragón, por lo que lo veremos desempeñar un papel de primer orden en los acontecimientos más importantes de la época, tanto en lo relativo a cuestiones fiscales, como políticas, así que podremos verlo actuar en la corte y, por tanto, con repercusiones en toda la Corona de Castilla, y, más concretamente, en el ámbito sevillano, con el que siempre mantuvo conexiones e influencias muy directas y al que, a pesar de sus prolongadas estancias en la corte, nunca renunció.

Como es bien sabido, entre los sucesos más importantes y trágicos que tuvieron lugar durante la minoría de Enrique III, destacan, sin lugar a duda, los asaltos a las juderías castellanas de 1391, que dieron comienzo en Sevilla y que, a partir

50 El 3 de mayo de 1385, el concejo ordenó que se pagasen 50 mrs. al jurado Nicolás Martínez y 200 mrs. al alguacil Gil Martínez de Pernía, para los gastos del viaje que debían realizar a los lugares de la Sierra, por orden y en servicio de Sevilla. Ese mismo día, la ciudad mandó al mayordomo que entregase a Nicolás Matínez 840 mrs. para que pagase sueldo de ocho días a los quince ballesteros y quince lanceros que se concentrarían en Aracena, para prestar servicio en el castillo de Aroche, así como que diesen al alguacil Gil Martínez de Pernía 600 mrs., para pagar sueldo de ocho días a sesenta soldados, veinte ballesteros y cuarenta lanceros, que deberían ir a Zufre, Santaolla, Real y Almadén para defender el mismo lugar de Aroche (AMS, Papeles de Mayordomazgo, 1384-1386, docs. $n .31$ y 34 . COLLANTES DE TERÁN, F: Inventario de los Papeles del Mayordomazgo del siglo XIV..., pp. 27-28).

51 Pedro Jiménez, comisionado por la ciudad a tal efecto, hace relación al concejo de Sevilla de lo que había recaudado de los jurados de los barrios y collaciones de la ciudad, entre ellos el barrio de Génova, a razón de 15 mrs. por ciento, de las cuantías de sus vecinos, con el fin de armar tres galeras y otras naos que Juan I mandó pedir a Sevilla para el sitio de Lisboa (AMS, Papeles de Mayordomazgo, 1384-1386, doc. n.ำ 137. COLLANTES DE TERÁN, F.: Inventario de los Papeles del Mayordomazgo del siglo XIV..., p. 47).

52 Nicolás Martínez hace relación al concejo de Sevilla de que había entregado al concejo de Arcos de la Frontera los 6.111 mrs. 1 dinero y 1 tomín, que había supuesto la renta del almojarifazgo de la villa, para pagar las velas y rodas de la villa y las labores de sus muros (AMS, Papeles de Mayordomazgo, 1386-1396: LABORES EN LOS CASTILLOS, doc. n.ํ 31. COLLANTES DE TERÁN, F.: Inventario de los Papeles del Mayordomazgo del siglo XIV..., p. 104). MONTES ROMERO-CAMACHO, I.: «La polémica del testamento de Juan I de Castilla y sus implicaciones sevillanas». Historia. Instituciones. Documentos, Homenaje al profesor José Martínez Gijón, 25 (1999), pp. 435-472. 
de esta ciudad, se extenderían, como un reguero de pólvora, a toda la Península, por lo que, tan pronto como alcanzó la mayoría de edad, en 1395, el nuevo rey viajó a Andalucía y, concretamente, a Sevilla, con el objetivo de castigar a los culpables, en un doble intento de restañar las profundas heridas causadas por los asaltos a las juderías y de reafirmar la autoridad monárquica, bastante deteriorada durante su minoría ${ }^{53}$. Entre otras medidas, el monarca impuso al pueblo sevillano, el autor material del asalto al barrio judío, una multa de 135.500 doblas de oro moriscas, que la ciudad debería satisfacer al rey en razón del robo que fue fecho a los judíos y judería desta çibdat, encargando el cobro de esta multa a dos conocidos conversos sevillanos: Alfonso Sánchez de Sevilla, hijo del que fuera famoso contador real Juan Sánchez de Sevilla ${ }^{54}$, y, especialmente, Nicolás Martínez de Medina, veinticuatro de Sevilla y, ya por entonces, contador mayor de Enrique III. La recaudación de la multa se prolongó, al menos, desde 1396 a 1404, por lo que, todavía en octubre de 1405, el mayordomo de Sevilla liquidaba los últimos plazos a Nicolás Martínez de Medina, tesorero del rey y su contador mayor, y a sus delegados, Juan Guillén de la Sal y Alfonso Sánchez de Sevilla ${ }^{55}$, pero no sería hasta 1409 cuando Nicolás Martínez de Medina, veinticuatro de Sevilla y contador mayor del rey, obtuvo de Enrique III la carta de perdón y quitamiento de esta multa, impuesta por el robo de la judería sevillana, quien habría de retenerla en su poder hasta que en 1410

53 MONTES ROMERO-CAMACHO, I.: «Antisemitismo sevillano en la Baja Edad Media: el «pogrom» de 1391 y sus consecuencias». Actas del III Coloquio de Historia Medieval Andaluza: Grupos no-privilegiados, Jaén, 1984, pp. 57-75 y Sefárdica: 1992: El descubrimiento de la cultura sefardí, año 6, n.ำ Buenos Aires, 1992, pp. 71-89 y «El antijudaísmo o antisemitismo sevillano hacia la minoría hebrea», Segundos Encuentros Judaicos de Tudela: «Los caminos del exilio», Pamplona, 1996, pp. 73-157. MITRE FERNÁNDEZ, E.: Los judíos de Castilla en tiempo de Enrique III. El pogrom de 1391. Valladolid, 1994,

54 Noticias sobre Juan Sánchez de Sevilla en MONTES ROMERO-CAMACHO, I.: «Juan Sánchez de Sevilla, antes Samuel Abravanel. Un modelo de converso sevillano anterior al asalto de la Judería de 1391. Datos para una biografía", Aragón en la Edad Media, Homenaje a la profesora Carmen Orcástegui Gros, n.․ XIV-XV, Zaragoza, 1999, pp. 1099-1113.

${ }_{55}$ El 14 de octubre de 1405, Sevilla ordenaba a su mayordomo que de las doblas de oro moriscas que recaudaba de la renta de los cueros a pelo, vendiese 1.900 en las tiendas de los cambiadores de la ciudad e hiciera llegar los maravedíes que valiesen a Nicolás Martínez de Medina, tesorero del rey y su contador mayor, a cuenta de las doblas de oro que Sevilla debía de pagar al rey por la muerte y robo de los judíos de esta ciudad. A continuación aparecen siete cartas de pago, fechadas desde el 22 de noviembre de 1404 hasta el 2 de septiembre de 1405, firmadas, en nombre de Nicolás Martínez de Medina, dos por Juan Guillén de la Sal y cinco por Alfonso Sánchez de Sevilla, de distintas cantidades entregadas por el mayordomo de Sevilla, Juan Martínez Armador, por este mismo concepto. Se incluyen también dos testimonios de los contadores y escribanos acerca de lo que valieron en las tiendas de los cambiadores de la calle de Génova, por una parte las 1.900 doblas y, por otra, las 600 doblas de oro moriscas de la renta de los cueros a pelo, que el mayordomo Juan Martínez vendió por orden de Sevilla, en octubre de 1405, para pagar la multa. A continuación viene el testimonio de Sevilla de haber recibido del mayordomo Juan Martínez dos cartas de pago, fechadas el 16 y el 17 de octubre de 1405, de Nicolás Martínez de Medina, de 43.500 y 137.750 mrs. a cuenta de las doblas de la multa. Finalmente, aparece el mandamiento de Sevilla a los contadores, datado el 24 de junio de 1406, para que recibiesen en cuenta al mayordomo las 2.500 doblas de oro moriscas que, por mandato de la ciudad, había vendido para pagar los maravedíes a los que se refieren las dos cartas de pago anteriores (AMS, Papeles de Mayordomazgo, 1404, doc. n. 97 y 1405, doc. n. 31. COLLANTES DE TERÁN, F.: Inventario de los Papeles del Mayordomazgo del siglo XV, tomo I: 1401-1416..., pp. 99 y 116-117). 
la ciudad le liquidó el importe de su comisión ${ }^{56}$. Como hemos podido comprobar, Nicolás Martínez de Medina representó un papel de primer orden en todo lo relativo al cobro de esta multa y, finalmente, en la obtención de la carta de perdón y quitamiento de Enrique III, algo que, a primera vista, puede resultarnos contradictorio, si tenemos en cuenta su parentesco con Ferrant Martínez, arcediano de Écija en la Iglesia de Sevilla, verdadero inductor ideológico del asalto a la judería sevillana en 1391, pero que, al mismo tiempo, nos demuestra el protagonismo que los conversos -y concretamente Nicolás Martínez de Medina y sus parientes- seguían manteniendo en este tiempo, tanto en Sevilla como en el entorno real.

Así pues, de los datos anteriores, podemos deducir que, por estos mismos años del reinado efectivo de Enrique III (1395-1406), Nicolás Martínez seguía desplegando una intensa y doble actividad, tanto en la corte, como en Sevilla. Así, una noticia de 1400 nos lo presenta ya como tesorero de Enrique III - llegaría a ser, como sabemos, su contador mayor-, veinticuatro de Sevilla y su procurador en la corte ${ }^{57}$.

Otra de las actuaciones más notables de Nicolás Martínez de Medina, esta vez durante la minoría de Juan II y dada su proximidad a su tío, el infante don Fernando, regente de Castilla junto con la madre del rey niño, Catalina de Lancaster, fue todo lo relativo a recaudar los recursos económicos necesarios para la campaña granadina que habría de culminar con la toma de Antequera en 1410, principalmente a través de los servicios de cortes, conquista en la que Sevilla, una vez más, representaría un papel de primer orden ${ }^{58}$. Pero veamos cuáles fueron las fases más importantes y cómo se llevó a cabo este complejo proceso, dirigido, una vez más, por el converso sevillano Nicolás Martínez de Medina.

${ }^{56}$ Mandamiento de Sevilla al mayordomo Juan Fernández de Mendoza, el 22 de noviembre de 1409, para que pagase a Nicolás Martínez de Medina, veinticuatro y contador mayor del rey, 200 doblas de oro moriscas, en concepto de los gastos y el trabajo que había hecho para que Enrique III le mandase librar la carta de perdón y quitamiento del robo de la judería de Sevilla, carta que Nicolás Martínez retenía hasta que Sevilla le pagase, pero que la ciudad necesitaba presentar, ya que el rey Juan II le había ordenado pagar a Luis Méndez Portocarrero 10.000 mrs. anuales, que le correspondían por privilegio real en la Aljama de los judíos de Sevilla, por causa de dicho robo. El 13 de agosto de 1410, Sevilla ordenaba a Juan Fernández de Mendoza, mayordomo del concejo en el año fiscal de 1409-1410, que pagase a Nicolás Martínez de Medina las 200 doblas de oro moriscas, o bien su equivalencia de 20.00 maravedíes, pero finalmente fueron pagadas por el mayordomo Suer Vázquez de Moscoso, nuevo mayordomo del periodo hacendístico de 1410-1411, ya que Juan Fernández de Mendoza adujo que no le cabían en su cuenta ni tenía dinero de Sevilla para efectuar el pago (AMS, Papeles de Mayordomazgo, 1409, doc. n. 67,1410 , docs. n.ำ 129, 156. COLLANTES DE TERÁN, F: Inventario de los Papeles del Mayordomazgo del siglo XV, tomo I: 1401-1416..., pp. 297, 348).

57 El 14 de julio de 1400, Sevilla ordenaba al mayordomo Alonso Pérez de Godoy, que pagase 6.000 mrs. a Nicolás Martínez, tesorero del rey y veinticuatro de Sevilla, para hacer frente a los gastos de su viaje a la Casa del Rey, como procurador de la ciudad (AMS, Papeles de Mayordomazgo, 1400-1401, doc. n. 16. COLLANTES DE TERÁN, F.: Inventario de los Papeles del Mayordomazgo del siglo XIV..., p. 84)

58 MONTES ROMERO-CAMACHO, I.: «Una nueva estrategia para una vieja guerra. La preparación en Sevilla de la campaña de Antequera (1410)", Historia. Instituciones. Documentos, Homenaje al profesor Julio Valdeón Baruque, 31, (2009), pp. 417-436. 
A principios de 1408, las Cortes se reunieron en Guadalajara, siendo su objetivo principal obtener nuevos recursos para reanudar la ofensiva contra el emirato nazarita, acaudillada, como la campaña anterior de 1407, por el infante don Fernando, que pidió a los procuradores un servicio de sesenta cuentos de maravedíes, teniendo en cuenta las deudas que todavía quedaban por pagar de la campaña de 1407 y los grandes gastos que se preveían, cantidad que levantó las protestas de los representantes populares, quienes adujeron que Castilla aún no se había recuperado del pago de los cuarenta y cinco cuentos del año anterior, aunque finalmente no tuvieron más remedio que plegarse a las demandas de la corona y otorgar los sesenta cuentos ${ }^{59}$.

El 17 de marzo de 1408, desde Guadalajara, Juan II escribía a los concejos de Sevilla y Cádiz y de las ciudades, villas y lugares de su arzobispado, con el obispado de Cádiz, ordenándoles recaudar entre sus vecinos y moradores los 385.867 maravedíes que correspondían a Sevilla y su tierra de los (primeros) diez cuentos de maravedíes que las Cortes de Guadalajara concedieron a la corona para los gastos de la guerra de Granada y que debían entregar a Nicolás Martínez, contador del rey y su tesorero mayor del pedido en el reino de Toledo y Andalucía, carta obedecida por el cabildo hispalense, que ordenó repartir dicho pedido por las nuevas cuantías que hicieran los veinticuatros Pedro Rodríguez de Esquivel (cuñado de Nicolás Martínez de Medina) y Juan Rodríguez de Hoyos, en la ciudad y los pueblos de la tierra ${ }^{60}$.

Una vez más, contamos con una rica información acerca de la contribución de Sevilla al pedido aprobado por las Cortes de Guadalajara de 1408, del que fue recaudador Nicolás Martínez de Medina, contador mayor del rey y tesorero mayor del pedido y monedas del reino de Toledo y de Andalucía, con el reino de Murcia y de otros obispados y merindades de Castilla, siendo sus recaudadores en SeviIla los veinticuatros Diego Ortiz, su sobrino, y su futuro yerno, Luis Fernández del Marmolejo ${ }^{61}$. Con el fin de proceder a la recaudación de este pedido, se encargó a los veinticuatros sevillanos Pedro Rodríguez de Esquivel (cuñado de Nicolás Martínez de Medina) y Juan Rodríguez de Hoyos, la elaboración de nuevas cuantías de los vecinos y moradores pecheros de los pueblos de Sevilla, excluyéndose a los francos, que fueron hechas en abril de 1408, para que, de acuerdo con ellas, fueran repartidos los 200.000 maravedíes del pedido de este año, cuyo recauda-

59 Crónica de Juan II, Biblioteca de Autores Españoles, tomo LXVIII, Crónicas de los Reyes de Castilla, II, Madrid, 1953, año 1408, caps. II, III, p. 304.

60 AMS, Papeles de Mayordomazgo, 1408, doc. n. 43. COLLANTES DE TERÁN, F.: Inventario de los Papeles del Mayordomazgo del siglo XV, tomo I: 1401-1416..., p. 265.

61 El 20 de marzo de 1408, Nicolás Martínez, contador mayor del rey y su tesorero mayor del pedido y monedas del reino de Toledo y de Andalucía con el reino de Murcia y de otros obispados y merindades, otorgaba su poder a Diego Ortiz y a Luis Fernández del Marmolejo, veinticuatros de Sevilla, para que recaudasen en su nombre el pedido y monedas que la ciudad y su arzobispado, con el obispado de Cádiz, debían pagar al rey para la guerra con los moros, este año de 1408 (AMS, Papeles de Mayordomazgo, 1407, doc. n. 216. COLLANTES DE TERÁN, F.: Inventario de los Papeles del Mayordomazgo del siglo XV, tomo I: 1401-1416..., p. 251. ORTIZ DE ZÚÑIGA, D.: Anales..., 2, p. 319). 
dor era Nicolás Martínez, tesorero mayor del rey, y también los 50.000 maravedíes que se debían a Bernal González, recaudador mayor del pedido de este año, en pago de los que la ciudad le adeudaba del pecho de los francos del pedido de 1407 , del que fuera igualmente recaudador ${ }^{62}$.

El 24 de mayo de 1408, la ciudad ordenaba a los jurados de los barrios y collaciones de Sevilla que recaudasen de los vecinos y moradores de la ciudad y su tierra las cantidades correspondientes al pedido que el rey le mandó echar por su carta fechada en Guadalajara, el 17 de marzo de 1408, para contribuir a los gastos de la guerra con los moros, debiendo los jurados entregar lo recaudado a los veinticuatros Diego Ortiz y Luis Fernández del Marmolejo, recaudadores de este pedido por Nicolás Martínez, contador mayor del rey y su tesorero mayor de dicho pedido ${ }^{63}$.

Sin embargo, la recaudación del pedido quedó en suspenso temporalmente, al decidirse el aplazamiento de la ofensiva contra Granada y firmarse treguas con el emirato por ocho meses, que se cumplirían el 31 de agosto de 1408, por lo que los procuradores consiguieron primero una rebaja a cincuenta cuentos $y$, un poco después, que sólo se recaudasen en 1408 cuarenta cuentos y al año siguiente, los diez cuentos restantes.

Mientras tanto, como era habitual, la defensa de la frontera granadina seguía estando en manos de los caudillos andaluces, alguno tan próximo a Nicolás Martínez de Medina como Fernán Arias de Saavedra, alcaide de Cañete ${ }^{64}$.

Una vez cumplidas las treguas, Juan II, el 15 de septiembre de 1408, escribía a los concejos de Sevilla, Cádiz, Jerez de la Frontera, Écija y de las otras villas y lugares del arzobispado de Sevilla y el obispado de Cádiz, comunicándoles que las Cortes de Guadalajara de 1408 le habían concedido sesenta cuentos de maravedíes en monedas y en pedido para la guerra con los moros, de los que, por ahora y a cuenta de los mismos, habrían de recaudarse seis monedas y diez cuentos de maravedíes, de los que había mandado hacer repartimiento, pero que al haberse firmado tregua con el emirato nazarita, el rey había aceptado la petición de los procuradores de rebajar la cantidad solicitada a quince monedas y veinte cuentos de maravedíes, con el fin de pagar los sueldos de los hombres de guerra que conformaron la hueste del infante don Fernando, así como los que dejó por fronteros en Andalucía, cuando volvió a la Corte, y también a los que sirvieron

62 AMS, Papeles de Mayordomazgo, 1407, doc. n.․2 219. COLLANTES DE TERÁN, F.: Inventario de los Papeles del Mayordomazgo del siglo XV, tomo I: 1401-1416..., p. 252.

${ }^{63}$ Sevilla y su tierra deberían pagar 385.867 maravedíes, de los que correspondieron al cuerpo de la ciudad 219.282 maravedíes y 5 dineros y el resto a su tierra (AMS, Papeles de Mayordomazgo, 1407, doc. n. ${ }^{2}$ 227. COLLANTES DE TERÁN, F.: Inventario de los Papeles del Mayordomazgo del siglo XV, tomo I: $1401-1416 \ldots$, p. 254).

${ }^{64}$ El 24 de marzo de 1408, Fernán Arias de Saavedra, alcaide de Cañete, escribía al tesorero Nicolás Martínez de Medina, dándole cuenta de su victoria contra los moros, cuando salió a correr las comarcas de Ronda y Setenil (ORTIZ DE ZÚÑIGA, D.: Anales..., 2, p. 319). 
y sirven en la flota hasta que se firmaron las treguas, así como para atender a la reparación de las naves y pertrechos en las Atarazanas y todo lo que fuera necesario para continuar la guerra, cuando se cumplieran las treguas. Como algunas villas y lugares habían protestado porque ya habían contribuido en el primer repartimiento de los diez cuentos de maravedíes, el monarca ordenaba a Sevilla y a las demás ciudades y villas citadas, que hiciesen repartimiento entre sus vecinos y moradores de los maravedíes que a cada uno de ellos y a las demás villas y lugares de su tierra, recogidos en la carta del rey, les correspondiera en el repartimiento de los veinte cuentos de maravedíes y que, después de recaudarlos, los dieran a Nicolás Martínez, contador del rey y su tesorero mayor de este pedido en el reino de Toledo, Andalucía y en el reino de Murcia, haciendo descuento de lo que cada uno de los sobredichos lugares pagara del primer pedido de los diez cuentos de maravedíes ${ }^{65}$. Como consecuencia de esta carta real, Nicolás Martínez, contador del rey y su tesorero mayor del pedido y monedas en el reino de Murcia, enviaba su albalá a los concejos de Sevilla, Cádiz, Jerez de la Frontera, Écija y de las otras villas y lugares del arzobispado de Sevilla, con el obispado de Cádiz, para que, obedeciendo la carta del rey, repartiesen entre sus vecinos y moradores, exentos y no exentos, los maravedíes que las Cortes de Guadalajara habían concedido al monarca para la guerra contra Granada ${ }^{66}$.

Nuevamente, a finales de 1408, volvieron a convocarse las Cortes para el año siguiente, esta vez en Valladolid, con el mismo objetivo que el año anterior: deliberar sobre la guerra contra los moros, por lo que Sevilla, obedeciendo el mandamiento real, elegía como sus procuradores a los veinticuatros Nicolás Martínez de Medina y Alonso Fernández (del Marmolejo?) para representar a la ciudad en las Cortes de Valladolid de $1409^{67}$. Por lo que parece, las Cortes de Valladolid de 1409 concedieron un nuevo servicio, del que conocemos la contribución sevillana y que, otra vez, fue recaudado por Nicolás Martínez de Medina, contador mayor del rey y tesorero del pedido y las monedas del reino de Toledo y Andalucía, quien volvió a delegar su percepción en Sevilla, en su futuro yerno Luis Fernández del Marmolejo y en su sobrino Diego Ortiz, de acuerdo con el siguiente proceso:

El 19 de agosto de 1409, desde Palencia, Juan II escribía a los concejos de Sevilla y de las villas y lugares de su arzobispado con el obispado de Cádiz, para que repartiesen entre sus vecinos y moradores la mitad del pedido votado en las Cortes de Valladolid de 1409, con destino a la guerra que el infante don Fernando preparaba contra Granada, y que, una vez recaudado, lo confiasen a Nicolás Mar-

65 AMS, Papeles de Mayordomazgo, 1408, doc. n. 45. COLLANTES DE TERÁN, F.: Inventario de los Papeles del Mayordomazgo del siglo XV, tomo I: 1401-1416..., pp. 266-267.

66 AMS, Papeles de Mayordomazgo, 1408, doc. n.ำ 46. COLLANTES DE TERÁN, F.: Inventario de los Papeles del Mayordomazgo del siglo XV, tomo I: 1401-1416..., p. 267.

67 A este respecto, Sevilla ordenó al mayordomo Gonzalo Martínez de Oviedo que pagase 12.000 maravedíes a cada uno de estos procuradores, para que solventasen los gastos de su procuración (AMS, Papeles de Mayordomazgo, 1408, doc. n.ำ11. COLLANTES DE TERÁN, F.: Inventario de los Papeles del Mayordomazgo del siglo XV, tomo I: 1401-1416..., p. 258). 
tínez de Medina, contador mayor del rey y tesorero mayor de este pedido en los reinos de Toledo, Andalucía y Murcia ${ }^{68}$.

Ese mismo día está fechada la carta de Nicolás Martínez, contador mayor del rey y su tesorero mayor del pedido de 1409 en los reinos de Toledo, Andalucía y Murcia, dirigida a los concejos de Sevilla y de las villas y lugares de su arzobispado con el obispado de Cádiz, para que diesen lo recaudado de la mitad de este pedido a su sobrino Diego Ortiz y a su futuro yerno Luis Fernández del Marmolejo, veinticuatros, en los que el tesorero había delegado ${ }^{69}$.

El 18 de septiembre de 1409, Sevilla ordenaba a sus contadores que pagasen a Diego Ortiz y Luis Fernández del Marmolejo, recaudadores de los pedidos de 1408 y 1409, a razón 20 maravedíes por millar, según la avenencia a la que habían llegado con el concejo a cambio de recaudar estos pedido por sí mismos y hacerlos llegar sin quiebra a Nicolás Martínez, recaudador mayor de ambos pedidos ${ }^{70}$.

El 20 de septiembre de 1409, Sevilla escribía los concejos de Alcalá de Guadaira, Utrera, Lebrija y Las Cabezas de San Juan y a los de todas las villas y lugares de la tierra de Sevilla, comunicándoles el monto de maravedíes que tenían que pagar cada uno de ellos de la primera paga del pedido de 1409, para que, en el plazo de cinco días, lo enviasen a Sevilla y los diesen a Diego Ortiz y Luis Fernández del Marmolejo, recaudadores de este pedido por delegación Nicolás Martínez, recaudador mayor del mismo $^{71}$.

El 23 de septiembre de 1409, la ciudad ordenaba a los jurados de los barrios y collaciones de Sevilla que hicieran reparto entre sus vecinos y moradores de los maravedíes que correspondían al cuerpo de la ciudad de la mitad del pedido de 1409, que debían entregar, una vez recaudado, a su tesorero, Nicolás Martínez, dando órdenes al Alguacil Mayor de hacer ejecución en los bienes de todos aquellos que no quisieran pagar lo que les había sido repartido ${ }^{72}$.

El 14 de diciembre de 1409, desde Palencia, Juan II escribía al concejo de Sevilla y a los de las demás ciudades, villas y lugares de su arzobispado con el obispado de Cádiz, comunicándoles que las Cortes de Valladolid le habían concedido cuarenta cuentos de maravedíes, aparte de los que quedaron del pedido y monedas que ordenó recaudar en 1408 , destinados a la guerra que su tío el infante don Fernando estaba preparando contra los moros, pero que, mientras se re-

68 AMS, Papeles de Mayordomazgo, 1409, doc. n.ำ 125. COLLANTES DE TERÁN, F.: Inventario de los Papeles del Mayordomazgo del siglo XV, tomo I: 1401-1416..., p. 312.

69 AMS, Papeles de Mayordomazgo, 1409, doc. n.ำ 126. COLLANTES DE TERÁN, F.: Inventario de los Papeles del Mayordomazgo del siglo XV, tomo I: 1401-1416..., p. 312).

70 AMS, Papeles de Mayordomazgo, 1409, doc. n. 127. COLLANTES DE TERÁN, F.: Inventario de los Papeles del Mayordomazgo del siglo XV, tomo I: 1401-1416..., pp. 312-313).

71 AMS, Papeles de Mayordomazgo, 1409, doc. n.ำ 129. COLLANTES DE TERÁN, F.: Inventario de Ios Papeles del Mayordomazgo del siglo XV, tomo I: 1401-1416..., p. 313.

72 AMS, Papeles de Mayordomazgo, 1409, doc. n.ำ 128. COLLANTES DE TERÁN, F.: Inventario de los Papeles del Mayordomazgo del siglo XV, tomo I: 1401-1416..., p. 313. 
partía este pedido, las Cortes habían convenido que se recaudasen veinte cuentos de maravedíes, por lo que el rey ordenaba al concejo sevillano que recaudasen, en el menor tiempo posible, los maravedíes con los que debían contribuir la ciudad y las villas y lugares de su tierra y que se los diesen a Nicolás Martínez de Medina, contador mayor del rey y tesorero mayor de este pedido. El 22 de diciembre de 1409, Nicolás Martínez, contador mayor del rey y su tesorero mayor del pedido en los reinos de Toledo, Andalucía y Murcia, daba su poder a Diego Ortiz y Luis Fernández del Marmolejo para que recaudasen en su nombre lo que había correspondido a Sevilla y a las villas y lugares de su arzobispado con el obispado de Cádiz de este pedido de 1409, haciéndolo saber de esta manera al Cabildo. El 18 de enero de 1410, el concejo hispalense obedecía la carta real, ordenando su cumplimiento a los jurados de los barrios y collaciones de Sevilla, encargados de recaudar los maravedíes que habían correspondido a sus vecinos y moradores, así como de entregarlos a Diego Ortiz y a Luis Fernández del Marmolejo, recaudadores del pedido por delegación de Nicolás Martínez, su tesorero mayor ${ }^{73}$.

Ese mismo día, el 18 de enero de 1410, Sevilla comunicaba a los concejos de Alcalá de Guadaira, Utrera, Lebrija y Las Cabezas de San Juan y a los de todas las demás villas y lugares de su tierra, la cantidad que debían pagar cada uno en el repartimiento de la segunda paga del pedido de 1409 y les ordenaba entregarla, en el plazo de cinco días, en Sevilla a Diego Ortiz y a Luis Fernández del Marmolejo, recaudadores de este pedido, por delegación de su tesorero mayor, Nicolás Martínez ${ }^{74}$.

Pero, a pesar de que la ofensiva contra el emirato nazarí se había convertido en su objetivo principal, el infante don Fernando no dejaba de dirigir los asuntos sevillanos, ya que eran muchos sus intereses y sus aliados en Sevilla, por lo que ese mismo año 1410 ordenó que la ciudad fuera gobernada por turnos de un alcalde mayor y ocho veinticuatros, que deberían ser renovados cada cuatro meses. En el segundo turno de este año, entró el veinticuatro Nicolás Martínez de Medina ${ }^{75}$.

En febrero de 1410, el infante don Fernando abandonó la corte, por entonces en Valladolid, para dirigirse a Córdoba, con el fin de preparar la guerra contra Granada. Tan pronto como llegó a Córdoba, convocó a las ciudades para solicitarles nuevos servicios y a los grandes, con el fin de pedirles consejo sobre la entrada que proyectaba realizar en el emirato nazarita, que habría de culminar con la toma de Antequera. Nuevamente, el veinticuatro Nicolás Martínez de Medina representó a Sevilla, junto con el veinticuatro Pedro Rodríguez de Esquivel, su cuñado, y el jurado Gonzalo Díaz de Vergara, como procuradores en la Junta que el «rey» (el Infante en su nombre) mandó reunir en Córdoba, el 20 de abril de 1410, según

73 AMS, Papeles de Mayordomazgo, 1409, doc. n.ำ 133. COLLANTES DE TERÁN, F.: Inventario de los Papeles del Mayordomazgo del siglo XV, tomo I: 1401-1416..., pp. 314-315.

74 AMS, Papeles de Mayordomazgo, 1409, doc. n.ำ 134. COLLANTES DE TERÁN, F.: Inventario de los Papeles del Mayordomazgo del siglo XV, tomo I: 1401-1416..., p. 315.

75 ORTIZ DE ZUNNIIGA, D.: Anales... 2, p. 330. 
nos dice el documento, para decidir con su Consejo asuntos que cumplían al servicio del rey y a honra de sus reinos ${ }^{76}$. Una vez más, como ocurriera con los pedidos de los dos años anteriores, 1408 y 1409, conocemos muchos detalles de su recaudación en Sevilla:

El 22 de julio de 1410, desde el real sobre Antequera, donde acompañaba al Infante, Nicolás Martínez, contador mayor del rey y su tesorero mayor del pedido y monedas en los reinos de Toledo, Andalucía y Murcia, enviaba un albalá al concejo sevillano y a los de todas las villas y lugares de su arzobispado con el obispado de Cádiz, comunicándoles que había delegado en su yerno, el veinticuatro Luis Fernández del Marmolejo, la recaudación, este vez en solitario, del pedido y las monedas que Sevilla y su Tierra debían pagar al rey en $1410^{77}$.

Por lo que sabemos, dicho pedido se recaudó con arreglo a las cuantías de los vecinos y moradores de los barrios y collaciones de Sevilla, que hiciera el veinticuatro Pedro Rodríguez de Esquivel, cuñado de Nicolás Martínez, por las cuales se recogió la segunda paga del pedido de 1409 y volverían a utilizarse para repartir los 153.941 maravedíes. y 10 dineros correspondientes a Sevilla de la primera paga de los 461.925 maravedíes con los que debía contribuir Sevilla al pedido del rey de 1410, a razón de 175 maravedíes por ciento, que la ciudad tenía que dar al tesorero Nicolás Martínez de Sevilla o a su yerno, Luis Fernández del Marmolejo, encargado de recaudar este pedido en Sevilla, en su lugar ${ }^{78}$.

Conocemos la cuenta de lo que Sevilla tuvo que pagar al rey, en concepto de la primera paga del pedido exigido al cuerpo de la ciudad, en el mes de mayo de 1410, que fue recaudado por el veinticuatro Luis Fernández del Marmolejo, en nombre y con poder de su suegro, Nicolás Martínez de Sevilla, a quien el rey había nombrado recaudador mayor de dicho pedido ${ }^{79}$.

El 22 de julio de 1410, en el real sobre Antequera, el infante don Fernando, en nombre de Juan II, enviaba sobrecarta a Sevilla, comunicándole que en el repartimiento del pedido de 1410, concedido para la guerra contra los moros, la ciudad y su tierra debían aportar 692.737 maravedíes y 5 dineros y que como el cuerpo de la ciudad estaba exento de monedas, debería pagar las dos terceras partes en los meses de mayo a julio, a Nicolás Martínez de Sevilla, tesorero mayor de este pedido y monedas en los reinos de Toledo, Andalucía y Murcia, pero que después de este mandamiento el rey envió otra carta permitiendo a Sevilla y su tierra que

${ }^{76}$ El 5 de mayo de 1410, Sevilla mandó al mayordomo Juan Fernández de Mendoza que librara 4.000 maravedíes a los veinticuatros y 2.000 maravedíes al jurado, para atender a sus gastos (AMS, Papeles de Mayordomazgo, 1409, doc. n. 95. COLLANTES DE TERÁN, F.: Inventario de los Papeles del Mayordomazgo del siglo XV, tomo I: 1401-1416..., p. 303).

77 AMS, Papeles de Mayordomazgo, 1410, doc. n.ำ210. COLLANTES DE TERÁN, F.: Inventario de los Papeles del Mayordomazgo del siglo XV, tomo I: 1401-1416..., p. 360.

78 AMS, Papeles de Mayordomazgo, 1410, doc. n.ำ 211. COLLANTES DE TERÁN, F.: Inventario de Ios Papeles del Mayordomazgo del siglo XV, tomo I: 1401-1416..., pp. 360-361.

79 AMS, Papeles de Mayordomazgo, 1410, doc. n.ำ 212. COLLANTES DE TERÁN, F.: Inventario de los Papeles del Mayordomazgo del siglo XV, tomo I: 1401-1416..., p. 361. 
pagasen estos 692.737 maravedíes y 5 dineros en los meses de julio a octubre, en cuatro partes iguales, una vez descontados los que ya hubieran dado al tesorero, pero, por esta nueva carta, el monarca daba órdenes de que pagasen las dos terceras partes del pedido en el tiempo y en los plazos que se estipulaban en la primera carta, ya que se necesitaba urgentemente el dinero para pagar a los que prestaban servicio con el infante don Fernando en el real sobre Antequera, por lo que debían repartirse entre los vecinos y moradores de Sevilla y su tierra, de acuerdo con sus cuantías, los maravedíes que les correspondían. En cumplimiento de esta sobrecarta, Sevilla ordenó a los jurados de sus barrios y collaciones que repartiesen entre sus vecinos y moradores los 192.377 maravedíes y 1 dinero que les restaba por pagar del pedido de $1410^{80}$.

Una vez cobrado el pedido de 1410, Sevilla hizo relación de los maravedíes que ordenó librar en Luis Fernández del Marmolejo, veinticuatro y recaudador por Nicolás Martínez de Sevilla, contador y tesorero mayor del rey, de la contribución de Sevilla y su tierra al pedido de 1410 , que correspondían a la primera y segunda paga de este pedido, tanto del cuerpo de la ciudad como de los pueblos de su tierra $^{81}$.

La documentación sevillana es muy explícita acerca de la febril actividad desarrollada en todo el reino de Sevilla, durante los primeros meses de 1410, en la preparación de la campaña de Antequera, no sólo, como era habitual, en lo referente a la aportación de soldados y mantenimientos o a la contribución económica, en todo lo cual Sevilla siempre representaba un papel protagonista, sino que, además, en esta ocasión, en el alcázar sevillano se fabricaron y pusieron a punto las máquinas de guerra, entre otras lombardas y truenos, y todos los demás pertrechos necesarios para la toma por asalto de la plaza granadina ${ }^{82}$. El encargado de dirigir tan importante tarea, por delegación de la corona, fue Pedro Ortiz, sobrino, como sabemos, de Nicolás Martínez de Medina y, por estos años de preparación de la campaña de Antequera, alcabalero mayor del rey en Sevilla. El coste de fabricación de todo este material bélico fue aportado, como era natural, en su mayor parte por Nicolás Martínez de Medina, tesorero mayor del pedido y las monedas del reino de Toledo y Andalucía, con el reino de Murcia, a lo que se sumaría otra cantidad menor entregada por Ruy Fernández de Peñalosa, tesorero mayor del pedido y las monedas de Castilla, así como el alcance de la cuenta del alcabalero en los partidos de la alhóndiga del pan y del aceite de Sevilla, de ese año $1410^{83}$.

80 AMS, Papeles de Mayordomazgo, 1410, doc. n. ํㅜㄹ. COLLANTES DE TERÁN, F.: Inventario de Ios Papeles del Mayordomazgo del siglo XV, tomo I: 1401-1416..., p. 362.

81 AMS, Papeles de Mayordomazgo, 1410, doc. n.ำ 192. COLLANTES DE TERÁN, F.: Inventario de los Papeles del Mayordomazgo del siglo XV, tomo I: 1401-1416..., p. 355.

82 MONTES ROMERO-CAMACHO, I.: «Una nueva estrategia para una vieja guerra. La preparación en Sevilla de la campaña de Antequera (1410)», Historia. Instituciones. Documentos, Homenaje al profesor Julio Valdeón Baruque, 31, (2009), pp. 417-436.

${ }^{83}$ El coste total fue de 904.093 mrs. y 6 dineros, de los que Nicolás Martínez de Medina aportó 650.000 maravedíes, Ruy Fernández de Peñalosa, 150.000 maravedíes y el alcance del alcabalero Pedro Ortiz fue de 104.093 maravedíes y 6 dineros (VILAPLANA MONTES, M. ${ }^{\text {a }}$ : «Un ajuste de cuen- 
Igualmente, el dinero recaudado por Nicolás Martínez de los servicios de estos años, también se empleaba en la leva de cereales a ciertas villas de la Campiña sevillana, caso de Estepa y Carmona, en 1409, tal vez con destino al abastecimiento de las plazas situadas en la primera línea de la Banda Morisca ${ }^{84}$. $\mathrm{O}$, como en 1410, cuando, por orden del monarca, Nicolás Martínez entregó a miçer Salagrús Bocanegra, por estos años de preparación de la campaña de Antequera, tesorero mayor del rey, una importante cantidad para dar, como mantenimientos y dádivas, a algunos moros granadinos que buscaban la protección regia y que, posiblemente, terminarían por convertirse en vasallos reales ${ }^{85}$. También, a veces, cuando el dinero de la tesorería de Nicolás Martínez se empleaba para otros fines que no eran los suyos propios, por mandamiento real, el mismo monarca ordenaba a sus otros agentes fiscales, en este caso el alcabalero Pedro Ortiz, que devolviese al tesorero lo prestado ${ }^{86}$.

Las cuentas del alcabalero Pedro Ortiz nos brindan también abundantes e interesantes noticias sobre Nicolás Martínez de Sevilla y su entorno más inmediato, tanto en lo relativo a su propia familia y allegados, como al personal dependiente de él, en su condición de contador mayor de Castilla, quienes, dada su proximidad a la corona, recibían importantes compensaciones económicas, en forma de mercedes, quitaciones tierras...

En el caso de nuestro protagonista, por ejemplo en 1408, el rey hizo merced a Nicolás Martínez, mi contador mayor de mis cuentas, de 20.000 maravedíes para ayuda de su mantenimiento y en 1409, Nicolás Martínez, mi contador mayor de mis cuentas, recibía 25.000 maravedíes, a cuenta de su quitación ${ }^{87}$.

De la misma manera, en 1408, el monarca otorgaba Johan Martínez, hijo de Nicolás Martínez, su contador mayor de las cuentas, tal vez por ser vasallo del rey, 1.900 maravedíes por su tierra, merced que le fue acrecentada en 4.500 maravedíes más por su tierra, para tres lanzas, a los que se añadieron otros 3.000 maravedíes que le habían sido concedidos al jurado Alfonso Fernández, para dos lanzas, difunto, por lo que en adelante, Johan Martínez cobraría de la corona 7.500

tas del alcabalero mayor de Sevilla Pedro Ortiz (1420)", Historia. Instituciones. Documentos, 1 (1974), pp. 419-501, vid. pp. 477-478).

${ }_{84}$ Cumpliendo el mandamiento real, Nicolás Martínez entregó a su sobrino Pedro Ortiz 80.000 maravedíes, para la cebada que el rey mandó llevar a las villas de Estepa y Carmona en 1409 (VILAPLANA MONTES, M. ${ }^{a}$ A: «Un ajuste de cuentas..., pp. 496-497).

${ }^{85}$ A miçer Salagrús Bocanegra, mi thesorero mayor de la mi casa, para en cuenta de çient mill marauedís. que el dicho thesorero Nicolás Martínez le ouo a dar de dozientos e çinquenta mill marauedís. que yo le enbié mandar que diese e pagase al dicho miçer Salagrús, para dar çiertos mantenimientos e dádivas a çiertos moros que se vinieron a la mi merçed del regno de Granada (VILAPLANA MONTES, M. ${ }^{a}$ A: «Un ajuste de cuentas... pp. 451, 473). ECHEVARRÍA ARSUAGA, A.: Caballeros en la frontera: La guardia morisca de los reyes de Castilla (1410-1467), Madrid, 2006.

${ }^{86}$ A Nicolás Martínez, mi contador mayor de las mis cuentas e mi thesorero mayor del pedido e monedas de los regnos de Toledo e del Andaluzía e Murçia el dicho año que pasó de mill e quatroçientos e nueue años, treinta mill marauedís, por quanto los dió e pagó por mi mandado de la dicha su thesorería del dicho año pasado. (VILAPLANA MONTES, M. a A: «Un ajuste de cuentas..., p. 473).

${ }^{87}$ VILAPLANA MONTES, M. ${ }^{a}$ A: «Un ajuste de cuentas..., pp. 445 y 461. 
maravedíes, para cinco lanzas, aunque de los 3.000 maravedíes acrecentados sólo 2.125 maravedíes, desde el 15 de abril — fecha de fallecimiento del juradohasta el 31 de diciembre, y en 1409 se le libraron otros 4.500 maravedíes de su tierra, para tres lanzas ${ }^{88}$.

Por su parte, en 1408, Johan Martínez de Sevilla, cobró 2.600 maravedíes de quitación, porque tenía los libros por Nicolás Martínez, contador mayor del rey ${ }^{89}$. Además, ese mismo año, Johan Martínez de Sevilla, cuñado de Ferrand Álvarez, contador, como vasallo real, recibía 1.500 maravedíes anuales de su tierra, para una lanza ${ }^{90}$. En 1409, Johan Martínez de Sevilla, cuñado de Ferrand Alvarez de Sevilla y contador del rey, que tenía los libros por Nicolás Martínez, contador mayor, percibía los 2.600 maravedíes de su quitación ${ }^{91}$ y en 1410, 1.500 maravedíes por su tierra, para una lanza ${ }^{92}$ y los 2.600 maravedíes de su quitación ${ }^{93}$.

Otro oficial de la corte, el doctor Fortún Velázquez, que, como tendremos ocasión de ver, Nicolás Martínez de Medina y su partido impondrán en 1416 como corregidor de Sevilla, en contra, nada menos, que del almirante don Alfonso Enríquez, recibía, en 1408, 120 maravedíes diarios, por merced real, para su costa y mantenimiento ${ }^{94}$, merced que le fue acrecentada, al menos en los seis primeros meses de 1410, a 180 maravedíes, cuando, por orden del rey, viajó a Andalucía ${ }^{95}$.

E igualmente, las cuentas del alcabalero Pedro Ortiz nos proporcionan información acerca de algunos grandes nobles, que desempeñaban un papel de primer orden en la corte castellana y muy próximos a Nicolás Martínez de Medina y sus parientes, como, por ejemplo, el condestable Ruy López Dávalos, a quien, en 1403, el alcabalero real Pedro Ortiz, su vasallo, pagó, por orden de Enrique III, 300.000 maravedíes, para ayuda de su costa e con que pudiese sostener la gente que tenia, y en 1408, 40.000 maravedíes a cuenta de los 100.000 que Juan II le mandó librar para su mantenimiento, los quales, el dicho señor Rey, mi padre, le mandaua dar cada año para su mantenimiento por sus alualaes ${ }^{96}$. O los Stúñiga, entre los que tomaremos como modelo a Lopez Ortiz de Astúñiga, mi guarda mayor y mi alcalde mayor de Sevilla, que, desde 1408 en adelante, recibía, por merced real, 15.000 maravedíes anuales de por vida, situados en la alcabala del

${ }^{88}$ VILAPLANA MONTES, M. ${ }^{\text {a }}$ A: «Un ajuste de cuentas..., pp. 451 y 455.

89 VILAPLANA MONTES, M. ${ }^{a}$ A: «Un ajuste de cuentas..., p. 442.

90 VILAPLANA MONTES, M. ${ }^{a}$ A: «Un ajuste de cuentas..., p. 447.

91 VILAPLANA MONTES, M. ${ }^{a}$ A: «Un ajuste de cuentas..., p. 460.

92 VILAPLANA MONTES, M. ${ }^{a}$ A: «Un ajuste de cuentas..., p. 464.

93 VILAPLANA MONTES, M. ㄹ A: «Un ajuste de cuentas..., p. 472.

94 VILAPLANA MONTES, M. ${ }^{a}$ A: «Un ajuste de cuentas..., p. 446.

95 Al doctor Furtún Velázquez, que fué mi merçed de le mandar dar para su mantenimiento de los meses de enero e febrero e março e abrill e mayo e junio del dicho año (1410), a razón de çiento e ochenta marauedís cada día, por quanto le mandé estar en el Andaluzía a fazer algunas cosas que cunplían a mi seruiçio, treynta e dos mill e quatroçientos marauedís (VILAPLANA MONTES, M. ${ }^{a}$ A: «Un ajuste de cuentas..., p. 473).

96 VILAPLANA MONTES, M. ํ A: «Un ajuste de cuentas..., pp. 432 y 450. 
pescado salado de Sevilla, merced que, por desgracia, quedó sin efecto por su muerte, el 6 de mayo de 1410, en el cerco de Antequera ${ }^{97}$.

Pero, sin duda, el principal beneficiario de la hacienda real castellana, por estos años, fue el infante don Fernando, en primer lugar porque, como regente del rey niño, Juan II, junto con la reina madre, doña Catalina de Lancaster, era el que tomaba las decisiones económicas y fiscales más importantes, que eran llevadas a la práctica por el tesorero mayor del rey, Miçer Salagrús Bocanegra, como ocurrió, por ejemplo, en $1410^{98}$. Pero, tal vez, lo que nos puede resultar más interesante, sean las grandes cantidades que el Infante, a través de Johan García de Paredes, su tesorero mayor, cobraba de la hacienda real castellana. Por ejemplo, ese mismo año de 1410, en primer lugar, don Fernando percibió 200.000 maravedíes en concepto del diezmo de la tutela de las rentas de las alcabalas, tercias y almojarifazgo, entre otras ${ }^{99}$. Igualmente se le dieron otros 400.000 maravedíes para pagar, durante ese año 1410, el sueldo de los doscientos lanceros de su guardia personal ${ }^{100}$. Pero, sin duda, la partida más importante es la que recibió, también en 1410, de cuatro cuentos de maravedíes, para atender a los grandes gastos que le suponía su candidatura a la corona de Aragón, que le había sido propuesta por sus partidarios aragoneses, en plena campaña de Antequera ${ }^{101}$.

Como es sabido, la victoriosa campaña de Antequera terminó con la rendición de la plaza al infante don Fernando, el 24 de septiembre de 1410, pero, aun así, en 1411 volvió a cobrarse un pedido, no sabemos si uno nuevo o los restos del pedido del año anterior, que, esta vez, por lo que se refiere al reino de Sevilla, fue

97 ... E por quanto el dicho Lope Ortiz murió en la batalla que el Infante, mi tío, ouo con los ynfantes moros sobre la mi villa de Antequera, a seys días de mayo del dicho año de mil e quatrosçientos e diez años, ouo de auer el terçio primero del dicho año de los dichos quinze mil marauedís, que son çinco mill marauedís. Los quales se vos resçibieron en cuenta del dicho año (VILAPLANA MONTES, M. ${ }^{\text {a }}$ A: «Un ajuste de cuentas..., pp. 447 y 476$)$.

${ }_{98}$ A miçer Salagrús, mi thesorero mayor de la mi casa, en cuenta de vn quento de marauedis que fue ordenado por la Reyna mi señora, mi madre, y por el dicho Infante mi tío, mis tutores y regidores de los mis regnos, que le fueron librados para que los despendiese por mandado del dicho Infante mi tío dozientos e çinquenta mill marauedís (VILAPLANA MONTES, M. ${ }^{\text {a }}$ A: «Un ajuste de cuentas..., p. 474).

99 A Johan Garçía de Paredes, thesorero mayor del Infante don Fernando, mi tío, que ouo de auer por el dicho Infante, en cuenta del diezmo de la tutela del dicho Infante, de todos los marauedís que ryndieron e montaron las rentas de las alcaualas e terçias e almoxarifadgos e otras çiertas rentas de mis regnos, asi commo mi tutor e regidor de los mis regnos, dozientos mill maravedís (VILAPLANA MONTES, M. a A: «Un ajuste de cuentas..., p. 474).

100 Al dicho Infante don Fernando, mi tío, en cuenta de un quento e treinta e seys mill e ochoçientos marauedís, que fue mi merçed de le mandar librar sueldo de todo el dicho año para dozientas lanças que andauan con él en su guarda, a razón de quinze maravedís cada día, quatroçientos mill marauedís. Los quales ouo de auer por él el dicho Johan García de Paredes, su thesorero mayor (VILAPLANA MONTES, M. ${ }^{\text {a }}$ A: «Un ajuste de cuentas..., p. 474).

101 Por otra mi carta, al Rey de Aragón, mi muy caro e muy amado tío, mi tutor, regidor de los mis regnos, para en cuenta de quatro quentos de maravedís, que fue mi merced de le mandar librar para ayuda de las grandes costas e despensas que fizo en la prosecución de los sus regnos de Aragón, nouenta mill e sesenta marauedís, los quales ouo de auer por él Johan Garçia de Paredes, su thesorero mayor, segund lo mostró por recabdo çierto ante los mis contadores mayores, que son todos çiento e tres mill e çiento e veynte e quatro marauedís e vn dinero (VILAPLANA MONTES, M. ${ }^{\text {A }}$ : "Un ajuste de cuentas..., pp. 499-500). 
recaudado por el jurado Pedro Fernández ¿de Córdoba?, contador mayor de la ciudad, en nombre del tesorero Nicolás Martínez de Sevilla ${ }^{102}$.

Sea como fuere, Nicolás Martínez de Medina y los suyos, siguieron contando con la protección directa del nuevo rey de Aragón, que continuaba dirigiendo los asuntos castellanos y al que siempre permanecieron fieles, mientras vivió y, una vez muerto, esta misma fidelidad la personificaron en sus hijos, los llamados Infantes de Aragón. Por todo ello no debe resultarnos extraño que cuando, el 30 de junio de 1412, el infante don Fernando de Antequera, comunica a Sevilla la noticia de su elección como rey de Aragón, encomiende la guarda y gobierno de Sevilla al adelantado Per Afán de Ribera y dejar en las cuentas a Nicolás Martínez de Medina y a Pedro Fernández de Córdoba, veinticuatro de Sevilla, que estaba bajo su tutela y que, como sabemos, ya empezaba a despuntar, en la corte y en Sevilla, a la sombra y con el modelo de su mentor ${ }^{103}$.

A este respecto, don Diego Ortiz de Zúñiga nos cuenta que cuando, en 1415, se reunió el Concilio de Constanza, participaron en él, como representantes del maestre de Santiago, el infante don Enrique de Aragón, don Vidal de Soto y Mosén García de Vergara, que posteriormente fue comendador de Mures y Benazuza y que, por tanto, se naturalizó en Sevilla, contrayendo matrimonio con doña Beatriz Fernández de Córdoba, hija de Pedro Fernández de Córdoba, contador de cuentas de Castilla con el tesorero Nicolás Martínez de Medina, por parte de la tutela del rey de Aragón ${ }^{104}$.

Mientras, las noticias sobre la carrera ascendente de Nicolás Martínez de Medina y de su familia inmediata, por lo que se refiere al contexto sevillano, continúan, aunque, esta vez, son las últimas, en cuanto a su vida pública, acerca de su segundo hijo varón, Juan, el único que podría haber continuado su obra, ya que su primogénito, Diego, era, como sabemos, fraile jerónimo en Guadalupe. Así, el 8 de julio de 1412, desde Cuenca, Juan II enviaba su carta al concejo de Sevilla confirmando el nombramiento que había hecho del mayordomo hijosdalgo en Juan Martínez, hijo del tesorero Nicolás Martínez de Sevilla, y de mayordomo ciudadano en Alfonso Fernández, hijo de Alfonso Fernández del Marmolejo, para el año fiscal de 1412 a 1413, en lugar de Miçer Venturín Venzón y de Francisco Fernández de Marmolejo -quien, al parecer, se había negado a ser renovado en el cargo-, que, respectivamente, habían ostentado el oficio de mayordomos hijosdalgo y ciudadano, en el año fiscal anterior, de 1411 a 1412, y cuyo mandato había terminado el pasado día de San Juan ${ }^{105}$.

102 Libro del pedido del año 1411 de que fue recaudador el jurado Pedro Fernández, contador mayor de la ciudad, por el tesorero Nicolás Martínez de Sevilla (AMS, Papeles de Mayordomazgo, 1411, doc. $\mathrm{n}$. 177. COLLANTES DE TERÁN, F.: Inventario de los Papeles del Mayordomazgo del siglo XV, tomo I: 1401-1416..., p. 395).

103 ORTIZ DE ZÚÑIGA, D.: Anales..., 2, p. 345.

104 ORTIZ DE ZÚÑIGA, D.: Ídem. p. 350.

105 AMS, Papeles de Mayordomazgo, 1412, doc. n.ำ 9. COLLANTES DE TERÁN, F.: Inventario de los Papeles del Mayordomazgo del siglo XV, tomo I: 1401-1416..., p. 397. 
Al mismo tiempo, Nicolás Martínez conservaba su veinticuatría en el concejo sevillano, recibiendo la quitación que le correspondía por dicho oficio ${ }^{106}$.

Pero, por lo que se refiere a la política sevillana, una de sus actuaciones más importantes fue cuando, en 1416, se negó a aceptar al almirante Alonso Enríquez como corregidor, ya que, al parecer, era su enemigo y de todo el clan familiar de los Medina, por lo que decidió apoyar al corregidor Ortún Velázquez, candidato de los Stúñiga, y, en su opinión, más fácilmente manejable que el almirante. Ciertamente, Nicolás Martínez de Medina, al fin y al cabo un converso al servicio de la hacienda real castellana, por sí mismo, no contaba con el poder necesario para oponerse al nombramiento del almirante, uno de los miembros más destacados de la alta nobleza castellana y de la corte, más aún cuando su principal valedor, el Infante don Fernando, como rey de Aragón, no controlaba ya directamente la política castellana, además de que murió ese mismo año, aunque, para poder cumplir su objetivo, Nicolás Martínez de Medina, su familia y partidarios, pudieron contar, como siempre, con la alianza de don Ruy López Dávalos y de otros significados personajes del Consejo Real, muchos de ellos aliados de los Stúñiga. Según parece, la elección del corregidor fue un episodio más de la lucha de bandos que ensangrentó Sevilla este año de 1416, dado el enfrentamiento radical que existía entre los dos partidos principales que se disputaban el poder en la ciudad, uno encabezado nada menos que por el conde de Niebla, el principal noble sevillano, y el otro por don Pedro de Stúñiga, heredero de la gran familia castellana, con grandes intereses en el reino y en la ciudad de Sevilla, donde habían obtenido importantes donaciones de la nueva dinastía Trastámara, entre otras, las que habrían de ser sus casas mayores en Sevilla, el futuro palacio de Altamira, situadas en el antiguo barrio judío y que, antes del asalto de 1391, habían pertenecido a personajes judíos y conversos tan notables como Yusaph Pichón y Samuel Abravanel, bautizado con el nombre de Juan Sánchez de Sevilla ${ }^{107}$. En torno a estos dos altos nobles, respectivamente, se alineaban un buen número de miembros de la nobleza, castellana y sevillana, y de la oligarquía de Sevilla, muchos de ellos con amplia presencia tanto en la corte, como en la ciudad. Por su parte, Nicolás Martínez de Medina, que tomó partido por don Pedro de Stúñiga, arrastró a su bando a muchos de sus parientes y amigos, entre los que podemos destacar a sus sobrinos, Diego y Pedro Ortiz, vasallos, como sabemos del condestable Ruy López Dávalos, o a su yerno, Luis Fernández del Marmolejo, que, entre otros ilustres sevillanos, habría de sufrir el destierro de su ciudad, como consecuencia de

${ }^{106}$ El 10 de julio de 1415, Sevilla ordenaba a su mayordomo Fernando Ortiz que pagase 3.000 maravedíes al tesorero Nicolás Martínez, correspondientes a su quitación por el oficio de veinticuatría del año 1413, ya que no se los había librado Juan de las Casas, que ejerció el cargo de mayordomo en dicho año 1413 (AMS, Papeles de Mayordomazgo, 1415, doc. n.ำ19. COLLANTES DE TERÁN, F.: Inventario de los Papeles del Mayordomazgo del siglo XV, tomo I: 1401-1416..., p. 501).

107 MONTES ROMERO-CAMACHO, I.: «Los judíos de Sevilla y el futuro palacio de Altamira» y LORA SERRANO, G.: «Los propietarios del palacio de Altamira: la familia señorial de los Estúñiga», en Diego Oliva Alonso (coord.): La restauración del palacio de Altamira, Sevilla, Junta de Andalucía, 2005, pp. 88124 y $128-179$. 
la lucha de bandos. Por lo que sabemos, el bando de don Pedro de Stúñiga resultó triunfante y consiguió imponer como corregidor al doctor Fortún Velázquez, aunque, según nos refiere la crónica de Alvar García de Santamaría, en esta designación tuvo mucho que ver Nicolás Martínez de Medina, quien, dada su buena posición en la corte, contó con el consentimiento regio para que Fortún Velázquez fuera recibido como corregidor en Sevilla, el 20 de junio de $1416^{108}$. Sea como fuere, el nuevo corregidor no fue capaz de terminar con la lucha de bandos en Sevilla, que sólo cesó, al menos temporalmente y tras muchos intentos por parte de ilustres personajes como el obispo de Córdoba, cuando, a requerimiento de importantes nobles y caballeros de uno y otro bando, caso de don Pedro Ponce de León, señor de Marchena, y de don Martín Fernández Portocarrero, el conde de Niebla y don Pedro de Stúñiga llegaron a un acuerdo, el 1 de diciembre de 1416, en el que entraron Nicolás Martínez de Medina y sus parientes, esta vez como amigos del conde de Niebla y de don Pedro Ponce de León, los dos grandes nobles sevillanos, partido que también pudo contar, entre otros personajes, con el patriarca y arzobispo de Sevilla don Alonso de Exea, o con los alcaldes mayores de Sevilla, Juan Cerón y Juan Fernández de Mendoza, unidos también por lazos de parentesco con Nicolás Martínez de Medina. Este cambio de fidelidad por par-

108 Origen de los bandos en Sevilla (1416).

... E en Sevilla comenzaron los bandos; e eran de la una parte el conde de Niebla, e su hermano don Alonso, e don Pero Ponce de León; e de la otra don Pedro de Estúñiga. E era de su parte don Juan, hermano del conde de Niebla, por cuanto estaba desavenido del conde, e Fernán Arias de Saavedra. E por fuerza de armas éstos no se podían igualar con los de la parte del conde de Niebla, por cuanto en Sevilla eran más que estos los de la ciudad.

E en esta sazón estaba en Sevilla don Alvar Pérez de Guzmán por alguacil mayor de Sevilla; e eran alcaldes mayores de Sevilla Juan Fernández de Mendoza e Juan Cerón, e el dicho Pedro; e veinticuatros Niculás Martínez, contador de las cuentas del Rey, e Alonso Fernández de Melgarejo, e García Fernández, su hermano, e Suer Vázquez de Moscoso, e Fernán Yáñez de Mendoza, e Pedro de Torres el Mozo, e Rui Gómez de Medina, e Rui Diaz de Cuadro, e Manuel Salagrús, e Pero de Ribera, e Alvar García de Cáceres, Rodrigo de Medina, Alonso Fernández, Rodrigo de Esquivel, Juan Fernández Marmolejo, Luis Fernández de Marmolejo, Pedro Ortiz e Diego Ortiz, Rui López, escribano, Pero Fernández Destor, mosén Diego de Vadillo, Pero Díaz de Sandoval, Sancho Sánchez de Carranza, Juan Barba, Diego de Tovar.

... E este Niculás Martínez, contador, que diximos, estorbaba mucho que no fuese por corregidor este don Alonso Enríquez, por cuanto era muy contrario de sus parientes. No porque él lo pudiese estorbar, más traía maneras con el condestable (Ruy López Dávalos) e con otros del Consejo que le estorbasen. E desque esta manera entendió Diego López de Estúñiga, a quien también pesaba mucho la ida del dicho almirante al corregimiento, porque receló que lo tenía ansí por enemigo como a Fernán Velázquez, traxo maneras como quedó el dicho almirante. E ganó otra sobrecarta para que recibiesen al corregimiento a Fernán Velázquez, porque no fuese.

Niculás Martínez envió sus cartas a los dichos sus parientes e amigos, que recibiesen el doctor Fernán Velázquez, que no al dicho almirante; pues sabía que él no les tenía buena voluntad, e cada que quisiesen podrían echar dende al dicho doctor, lo que no podría facer al dicho almirante. E por ende, luego que llegaron las dichas cartas recibieron al dicho doctor, en veinte días de junio de 1416 años, por corregidor de Sevilla. E los que trataron este fecho fueron Diego Ortiz e Pero Ortiz su hermano, mostrándose por muy amigos del corregidor, e que por ende lo facían. E aún con atijaras con el dicho corregidor, librando con él sus faciendas; esto antes que viese la respuesta de nuestro señor el Rey, la cual mandaba que le oviesen por corregidor, sin embargo de sus razones. (GARCÍA DE SANTAMARÍA, A.: Crónica de Juan II de Castilla, cap. 411, ed. Carriazo y Arroquia, J. de M.: Anecdotario sevillano, Sevilla, 1947, p. 61, reed. Sevilla, 1988, pp. 35-38, n. $\left.{ }^{\circ} 16\right)$. 
te del contador y sus aliados nos demuestra, una vez más, lo camaleónico del comportamiento banderizo, general en todo el Occidente bajomedieval y perfectamente reconocible en la Castilla y la Sevilla de la época ${ }^{109}$.

Pero, a la vez que en Sevilla, Nicolás Martínez de Medina seguía participando en muchos asuntos de la alta política castellana, dada su sintonía con los Infantes de Aragón, tras la muerte de su padre, el infante don Fernando, rey de Aragón, en 1416, que, como él, seguían ejerciendo gran ascendiente sobre rey Juan II de Castilla y, por tanto, en la corte ${ }^{110}$. Así, en 1420, formaba parte del consejo del infante don Enrique, siendo uno de sus partidarios más activos, en sintonía con los dos grandes nobles sevillanos, el conde de Niebla y el señor de Marchena, y en oposición a su hermano, el infante don Juan, ya que ambos se disputaban la custodia y tutela de su primo, el rey de Castilla, aunque ya por entonces empezaba a dejarse sentir, sobre el monarca y parte de la nobleza cortesana, la influencia de don Álvaro de Luna ${ }^{111}$.

109 Pacificación de los bandos (1416).

Don Pedro Ponce de León, señor de Marchena, e Martín Fernández Portocarrero, viendo que los fechos se iban malparanado, e que no era servicio de Dios e del Rey lo que se facía, e aún que les caía en parte, que cada uno de ellos avia de ayudar a su parte, por ende, por parte de Martín Fernández fue movido que se viesen don Pero Ponce e él, por ver si podrían igualar al conde e a Pedro de Estúniga. E trabajaron en ello, ansí con la una parte como con la otra, tirando los contendimientos de cada uno. Que el conde tenía que en Sevilla Pedro de Estúñiga no se podía igualar con él. Pedro de Estúniga tenía que con la ayuda de su padre e de Juan de Velasco, que tenía su parte, e de sus hermanos, que se podía con él igualar, aquí en Sevilla e en la corte.

E plogo a Dios que tales maneras troxieron entre ellos, que los igualaron, en esta manera. Que don Juan, hermano del conde, e Pedro de Estúñiga e Martín Fernández, que fuesen amigos del conde, e don Pero Ponce de ellos. E cada uno puso en la tregua e amoríos sus aliados, en esta manera. El conde puso con don Pero Ponce de León e al patriarca e arzobispo de Sevilla, el tesorero de la iglesia, Juan Cerón e Juan Fernández de Mendoza, alcaldes mayores de Sevilla, como quiera que a ellos no les plugo dello, a Ruy Gómez de Medina, el tesorero Niculás Matínez e sus parientes, e el comendador de Chilque, e el comendador de la casa de Alcántara.

E de la parte de Pedro (de Estúniga) son estos que aquí dirá: Martín Fernández Portocarrero, miçer Gilio Bocanegra, Alonso Fernández de Melgarejo, e Fernán Ruiz Cabeza de Vaca, Fernán Arias de Saavedra, el comendador de Morón, fray Alvaro de Chércoles. E don Alonso no entró en esta amistanza, sólo por cuanto quedó que requiriese Pedro a Diego López, e Diego López que lo contentase, e don Alonso que tomase su mujer.

E esta amistad se acabó en martes, el sol puesto, en la iglesia de San Isidro, primero día de diciembre... (GARCÍA DE SANTAMARÍA, A.: Crónica de Juan II de Castilla, cap. 418, ed. Carriazo y Arroquia, J. de M.: Anecdotario sevillano, Sevilla, 1988, p. 43, n.을).

110 SUÁREZ FERNÁNDEZ, L.: «La época de los Infantes de Aragón», en Historia General de España y América, tomo V: Los Trastámara y la unidad española (1369-1517), Madrid, 1981, pp. 353-404, vid. especialmente pp. 355-359.

111 De como el Infante se tornó a Talavera e lo que hizo.

Vuelto el Infante don Enrique a Talavera, mandó llamar a consejo. Fueron con el Infante el Arzobispo de Santiago y el Conde de Niebla, e don Pero Ponce de León, e Diego Hernández de Quiñones, e Nicolás Martínez, Contador mayor del Rey, e los Doctores Juan González de Arévalo e Fernán Gonzalez de Ávila, e algunos de los Procuradores de las ciudades e villas que ende estaban; e lo que principalmente en este consejo se acordó fue que se procurase por todas las vías que se pudiesen porque el Rey no quedase en poder de los que con él iban, e como supieron quel Rey iba allende de Tajo, mandaron que se guardasen todos los pasos, porque no pudiese pasar gente alguna para el Rey de los que estaban aquende de Tajo. Para esto mandaron quebrar e anegar todos los barcos del rio de Tajo en aquella comarca, e mandaron poner muy gran guarda en las puertas de Toledo, porque por allí 
Dentro de este mismo contexto, que demuestra la doble proyección pública de Nicolás Martínez de Medina, tanto Sevilla como en la corte, a las que no renunció hasta el final de su vida, la magnífica posición económica que disfrutaba la familia de Nicolás Martínez de Sevilla, tesorero y contador mayor del rey, queda reflejada en el préstamo de 3.500 maravedíes que, también en 1420, su mujer dio a Sevilla, para que Diego Ortiz, veinticuatro y procurador de la ciudad, así como sobrino del tesorero, que se encontraba en la Corte, pudiese proseguir el pleito que la ciudad mantenía con don Pedro Ponce de León, señor de Marchena, acerca de los términos de Alcalá de Guadaira ${ }^{112}$.

Posiblemente, en 1421, el tesorero Nicolás Martínez de Sevilla continuaba en la corte, por lo que su criado Diego Fernández recibió del mayordomo de 200 maravedíes, por entregar en la corte al doctor Pedro Fernández y al jurado Pedro Fernández unas cartas que Sevilla les envió ${ }^{113}$.

Sea como fuere, Nicolás Martínez, seguía participando en los asuntos públicos sevillanos, por lo que el 4 de junio de 1425, Juan Gutiérrez Tello, su yerno, vecino de la collación de San Salvador, mayordomo elegido para el año 1425, presentó ante el concejo carta de fianza en la que aparecía como fiador Nicolás Martínez de Sevilla, contador mayor del rey, vecino de la collación de San Miguel ${ }^{114}$.

Aunque no por ello, ni siquiera dada su avanzada edad, dejó de estar presente en la corte, por más que don Álvaro de Luna había conseguido hacerse con el poder Castilla, como valido de Juan II, alejando de la escena política castellana, al menos temporalmente, a los Infantes de Aragón, principales valedores, especial-

no pudiesen pasar. Otrosí, proveyeron de embiar muchas viandas a la hueste del Condestable e de los Caballeros que eran idos en pos del Rey; lo qual fue mandado pregonar por los Alcaldes del Rey el sábado siguiente del viernes quel Rey dende partió, en el qual día el Infante fue certificado como el Rey estaba en el castillo de Montalván; e luego sin tardanza el Infante mandó que fuesen tomar la puente del Arzobispo que es sobre Tajo, a seis leguas de Talavera, porque por allí no pasase gente alguna ni otro socorro al castillo de Montalván. Y el Infante embió a Fernán Rodríguez de Monroy, señor de Belvis, a la tomar con treinta hombres de armas, e halló la puente tomada de Garci Álvarez de Toledo, señor de Oropesa, que le había embiado mandar Álvaro de Luna que la tomase, e dexase ende gente que la guardase e se volviese a Montalván, el qual lo puso así en obra; y el Infante asimesmo embió guardar los puertos con gente de caballo e de pie, porque no pasasen al Rey gentes en contrario de los que estaban en el Real. (PÉREZ DE GUZMÁN, F.: Crónica del Serenísimo Príncipe Don Juan, segundo rey de este nombre en Castilla y en León. Ed. Cayetano Rosell, Madrid, 1953 (B. A. E., t. LXVIII, Crónicas de los Reyes de Castilla, II), año 1420, cap. XXXI, p. 392).

112 El 26 de julio de 1420, Sevilla mandaba al hacedor de las rentas y propios que pagase estos 3.500 maravedíes a la mujer de Nicolás Martínez de Sevilla, tesorero y contador mayor del rey, de los cuales Diego Ortiz debería pagar 2.000 maravedíes al fiscal del rey y al letrado que le asistía en dicho pleito y 1.500 maravedíes al escribano que tenía a su cargo la relación del mismo y, además, tenía que dar 300 maravedíes a un trotero que debía llevar a la corte algunas cartas y escritura por orden del concejo sevillano (AMS, Papeles de Mayordomazgo, 1420, doc. n.ำ 46. COLLANTES DE TERÁN, F.: Inventario de los Papeles del Mayordomazgo del siglo XV, tomo II: 1417-1431, Sevilla, Excmo. Ayuntamiento de Sevilla, 1980, p. 78).

113 AMS, Papeles de Mayordomazgo, 1421, doc. n.ำ 109, XIII. COLLANTES DE TERÁN, F.: Inventario de los Papeles del Mayordomazgo del siglo XV, tomo II: 1417-1431..., p. 112.

114 AMS, Papeles de Mayordomazgo, 1425, doc. n.ํㅜ 3. COLLANTES DE TERÁN, F.: Inventario de los Papeles del Mayordomazgo del siglo XV, tomo II: 1417-1431..., p. 112. 
mente don Enrique, de Nicolás Martínez de Medina ${ }^{115}$. De esta manera, el 2 de julio de 1432, desde Valladolid, el converso Garci Sánchez de Sevilla, jurado, informaba al concejo sevillano de su actuación en la corte del rey, donde estaba con el tesorero Nicolás Martínez, veinticuatro, y con Juan Fernández de Mendoza, alcalde mayor, explicándole que, hasta entonces, no habían podido resolver los negocios que les habían delegado, ya que el condestable don Álvaro de Luna se encontraba ausente de la corte ${ }^{116}$. Por lo que parece, al menos, Garci Sánchez de Sevilla, jurado, y el tesorero Nicolás Martínez, veinticuatro, prolongaron su estancia en la corte, como procuradores de Sevilla, hasta conseguir llevar a buen término los asuntos que la ciudad les había encomendado ${ }^{117}$.

\section{CONCLUSIÓN}

Por lo que sabemos, Nicolás Martínez de Medina murió a finales de 1433 o principio de 1434, en Medina del Campo, donde se encontraba la corte.

Según don Diego Ortiz de Zúñiga, no llegó a concluir su testamento, aunque encomendó al rey sus hijos y delegó todos sus asuntos en el único hijo varón que le sobrevivió, fray Diego Martínez, quien procedió al reparto de la herencia, junto con sus seis hermanas, el 31 de agosto de 1434, según tuvimos ocasión de ver.

En cuanto a su enterramiento, don Diego Ortiz de Zúñiga deja entrever varias posibilidades, algunas de las cuales podrían ser perfectamente compatibles. Una de ellas es que, en un principio, su cadáver pudo estar depositado en la capilla de Santiago de la Catedral de Sevilla, donde también podría haber estado enterrado, al menos durante un tiempo, su hijo Diego Martínez, de lo que no hay constancia en el archivo catedralicio ${ }^{118}$. Otra, la más probable, que, a su fallecimiento, los restos hubieran sido inhumados en Medina del Campo, localidad originaria de la familia y lugar de su muerte, donde habría dotado una capilla, para después ser traslados a Sevilla por su hijo Diego, con el fin de ser enterrados en la capilla fundada por su padre, Martín Martínez de Medina, en el convento de San Francis-

115 SUÁREZ FERNÁNDEZ, L.: «La época de los Infantes de Aragón», en Historia General de España y América, tomo V: Los Trastámara y la unidad española (1369-1517), Madrid, 1981, pp. 353-404, vid. especialmente pp. 366-377.

${ }_{116}$ AMS, Papeles de Mayordomazgo, Ped. 1432 doc. n. ${ }^{-14}$. KIRSCHBERG SCHENCK, D.: Catálogo de los Papeles del Mayordomazgo del siglo XV, tomo III: 1432-1442, Excmo. Ayuntamiento de Sevilla, 2011, doc. n. 26 , p. 63.

117 El 3 de abril de 1433, el cabildo ordenaba a su mayordomo, Juan Gutiérrez Tello, yerno de Nicolás Martínez de Medina, que pagase a Garci Sánchez de Sevilla, jurado, los 2.000 maravedíes que costó sacar un cuaderno de respuestas a las peticiones de Sevilla y otras escrituras que se redactaron durante su estancia en la corte, como procurador, junto con el tesorero Nicolás Martínez (AMS, Papeles de Mayordomazgo, 1432-1433 docs. n.ำ 103, 183. KIRSCHBERG SCHENCK, D.: Catálogo de los Papeles del Mayordomazgo del siglo XV, tomo III: 1432-1442..., docs. n. ${ }^{\text {s }} 172,173$, p. 96).

118 ORTIZ DE ZÚÑIGA, D. : Anales..., 2, p. 271. 
co de Sevilla, donde ya yacía su mujer, Beatriz López de las Roelas, fallecida en torno a $1430^{119}$.

En opinión de Juan Gil, hizo testamento en Medina del Campo, fechado el 1 de marzo de 1434, según el cual decidió enterrarse en el convento de San Francisco de Sevilla, en la capilla que su familia poseía, ordenando que se labrasen en alabastro sendas estatuas yacentes a él, a su mujer y a sus padres, tomando como modelo las del adelantado Per Afán de Ribera y su mujer en la Cartuja de las Cuevas, e instituyendo en el mismo convento dos capellanías, dotadas con 5.000 maravedíes anuales. Además, dejó 1.000 maravedíes a la fábrica de la parroquia de San Vicente, donde estaban enterrados sus abuelos, Diego y María Fernández. Dio poder para cumplir su testamento a su hijo Diego, siendo testigos del mismo, entre otros, Alonso Álvarez de Toledo, contador del rey, su sobrino, el bachiller Pedro Álvarez de Alcalá, los escribanos reales Alonso Sánchez de Sevilla, Juan Martínez de Sevilla y Gonzalo García de Ocaña y el doctor Fernando Díaz de Toledo, oidor de la Audiencia real y su relator y secretario, entre los que podemos reconocer a conocidos conversos. Tanto el testamento, como el poder, recibieron la confirmación de Juan II, el 7 de abril de 1434, en Valladolid ${ }^{120}$.

Durante toda su vida se distinguió como un fiel servidor de la corona, en su condición de vasallo de los reyes, llegando a ostentar algunos de los más altos cargos de la administración castellana, especialmente los vinculados a la Hacienda real: último tesorero mayor de Andalucía, tesorero mayor del pedido en los reinos de Toledo, Andalucía y Murcia, contador mayor de cuentas, durante la minoría de Juan II, contador mayor de Castilla y miembro del Consejo Real. Paralelamente, fue ocupando, de forma progresiva, algunas magistraturas del concejo sevillano, empezando su carrera como jurado del barrio de Génova, donde se concentraba todo el entramado financiero de la ciudad, lugarteniente del mayordomo, veinticuatro, procurador del concejo... hasta convertirse en uno de los principales integrantes del cabildo sevillano, en el primer tercio del siglo XV.

Una carrera tan brillante, como la de otros conocidos conversos sevillanos, sólo pudo estar justificada, aparte de por sus extraordinarias cualidades y méritos personales, por su proximidad a la nueva dinastía Trastámara y, en su caso, especialmente al infante don Fernando (de Antequera), posteriormente elegido rey de Aragón, y, a su muerte, a sus hijos, los Infantes de Aragón, por lo que, tanto Nicolás Martínez de Medina, como sus parientes y amigos, recibieron siempre la protección de la corona, lo que les permitió escalar los más altos puestos, tanto en Sevilla, como en la corte, a pesar de su condición de conversos, llegando a constituir, en ocasiones, una auténtica trama familiar, social y política que habría de representar un papel de primer orden en la Sevilla y en la Castilla de la época, al menos desde la instauración de la dinastía Trastámara, en 1369, e incluso antes,

119 ORTIZ DE ZÚÑIGA, D.: Discurso..., p. 54.

120 GIL FERNÁNDEZ, J.: Los conversos y la Inquisición sevillana, vol. IV, Sevilla, 2001, pp. 444-445. 
en el caso de linajes protoconversos, como el de Nicolás Martínez de Medina, hasta el enrarecimiento de las relaciones entre cristianos viejos y conversos, que en Sevilla llegaría a su punto culminante con el establecimiento de la Inquisición, en 1480 .

Para su desgracia, Nicolás Martínez de Medina que, en su condición de caballero, posiblemente habría ambicionado para sus descendientes el acceso a la nobleza, no pudo ver perpetuado su apellido ni continuada su obra, al romperse la línea de varonía por la muerte prematura de su hijo Juan y el ingreso en la orden jerónima de su otro hijo Diego, los únicos varones de su numerosa prole. Como sabemos, fray Diego, además de poseedor de una extraordinaria cultura y buen poeta, fue el fundador del magnífico convento San Jerónimo de Buenavista, en Sevilla, a cuya construcción se aplicó una buena parte de la herencia de Nicolás Martínez de Medina y en el que quedó perpetuada su memoria y también en la abundante $y$, en muchos casos, distinguida prole de cuatro de sus seis hijas.

A este respecto, don Diego Ortiz de Zúñiga, el gran analista sevillano del siglo XVII, tan orgulloso siempre de sus orígenes nobles, no dudaba en reconocer a Nicolás Martínez de Medina y su familia, como algunos de sus ilustres antepasados, a pesar de sus orígenes protoconversos y de la obsesión de su tiempo por la limpieza de sangre, al decirnos que de las cuatro hijas del contador se siguió mucha y noble descendencia, "que abrazan toda la nobleza de esta ciudad y muchas de otras partes» ${ }^{121}$.

121 ORTIZ DE ZÚÑIGA, D.: Anales..., 2, año 1434, pp. 392, 396, 397, 398, 444. Como sabemos, de sus seis hijas, sólo una permaneció soltera, Juana Fernández Carrillo, mientras que Inés Martínez de Medina casó con Juan Gutiérrez Tello, Constanza Martínez Carrillo, con Juan Cerón, Leonor Martínez de Medina, con Luis Fernández Marmolejo, Beatriz López de las Roelas con Pedro Melgarejo e Isabel de las Roelas, posiblemente, con Ruy Díaz de Mendoza, matrimonio que, al parecer, no tuvo hijos. 
